\title{
Colletotrichum acutatum var. fioriniae (teleomorph: Glomerella acutata var. fioriniae var. nov.) infection of a scale insect
}

Jose Marcelino $^{1}$

Department of Plant and Soil Science, Entomology Research Laboratory, University of Vermont, 661 Spear Street, Burlington, Vermont 05405

Rosanna Giordano

Illinois Natural History Survey, Division of Biodiversity and Ecological Entomology, 1816 S. Oak Street, Champaign, Illinois 61820

Svetlana Gouli

Vladimir Gouli

Bruce L. Parker

Margaret Skinner

Entomology Research Laboratory, University of Vermont, 661 Spear Street, Burlington, Vermont 05405

David TeBeest

Department of Plant Pathology, Plant Science Building, University of Arkansas, Fayetteville, Arkansas 72701

Roberto Cesnik

EMBRAPA - Embrapa Meio Ambiente, CP 69, CEP 13820-000, Jaguariúna-SP, Brazil

Abstract: An epizootic has been reported in Fiorinia externa populations in New York, Connecticut, Pennsylvania and New Jersey. Infected insects have profuse sclerotial masses enclosing their bodies. The most commonly isolated microorganism from infected $F$. externa was Colletotrichum sp. A morphological and molecular characterization of this fungus indicated that it is closely related to phytopathogenic $C$. acutatum isolates. Isolates of Colletotrichum sp. from $F$. externa in areas of the epizootic were similar genetically and were named Colletotrichum acutatum var. fioriniae var. nov. based on our findings. In vitro and in planta mating observed between isolates of $C$. acutatum var. fioriniae could serve as a possible source of genetic variation and might give rise to new biotypes with a propensity to infect insects. Only one other strain, C. gloeosporioides f. sp. ortheziidae, has been reported to show entomopathogenic activity.

Key words: Colletotrichum acutatum var. fioriniae, entomopathogenic fungi, epizootic, Fiorinia externa

Accepted for publication 29 March 2008.

${ }^{1}$ Corresponding author. E-mail: jmarcelino@uac.pt
INTRODUCTION

The ascomycete Colletotrichum Corda (1831) is a widely occurring and intensively studied plant pathogen and research has focused on its effects on plants (Sutton 1992). One reported case of a member of this genus, C. gloeosporioides, causes epizootics on the scale insect Orthezia praelonga Douglas (1891) (Hemiptera: Coccoidea), a major pest of citrus in Brazil (FIG. 1S). It first was identified by Batista and Bezerra (1966) and morphologically confirmed by the Commonwealth Agriculture Bureau International, CABI (H.C. Evans, CABI Report 1990). Biological control of $O$. praelonga, using C. gloeosporioides, has been conducted in Brazil (Viegas et al 1995, Cesnik and Ferraz 2000) obtaining scale mortalities of $85-96 \%$ $70 \mathrm{~d}$ after application (Cesnik et al 1996).

For most Colletotrichum spp. the complete host range is unknown (Fagbola and Abang 2004). This genus is widely encountered in humid and subhumid tropics (Mills et al 1992, Waller 1992). Reports of new plant hosts are common. In New Zealand 39 hosts from 23 plant families have been reported (Simmonds 1965). Xiao et al (2004) recovered this genus from 23 cultivated and noncultivated hosts in westcentral Florida. In Japan Moriwaki et al (2002) isolated 25 Colletotrichum spp. from 123 species within families such as Gramineae, Poaceae, Leguminosae and Cucurbitaceae. An extensive record of Colletotrichum hosts was made by Lenné (1992), identifying nine species of the fungus associated with 102 species of plants (Sutton 1992).

Colletotrichum spp. employ different infection strategies in plants ranging from endophytic to hemibiotrophic and subcuticular intramural growth (Smith et al 1999). In many of the reported hosts, quiescent mesophyll intercellular mycelia instead of necrotrophic growth was observed (Wei et al 2004).

This paper presents the second report of a member of the genus Colletotrichum infecting an insect and the first report of infection of an insect by a species of Colletotrichum in North America. In 2002 a natural epizootic associated with a complex of fungi was observed in populations of elongate hemlock scale, Fiorinia externa Ferris (Hemiptera: Coccoidea), a pest of eastern hemlock (Tsuga canadensis [L.] Carrière) (McClure 2002).

$F$. externa occurs at higher densities within a $300 \mathrm{~km}$ radius of New York City (Danoff-Burg and Bird 2002), and its distribution spans from southern 

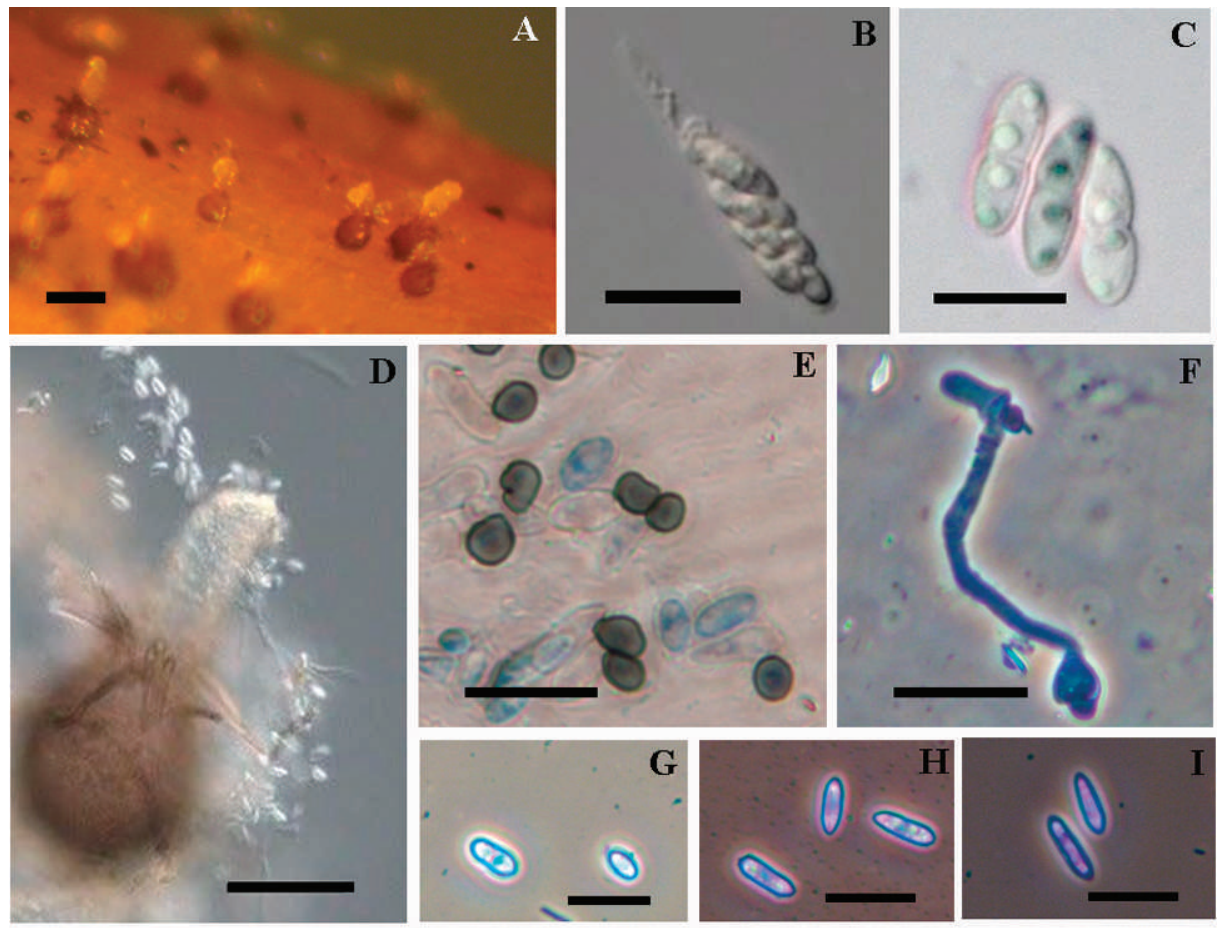

$\mathbf{E}$
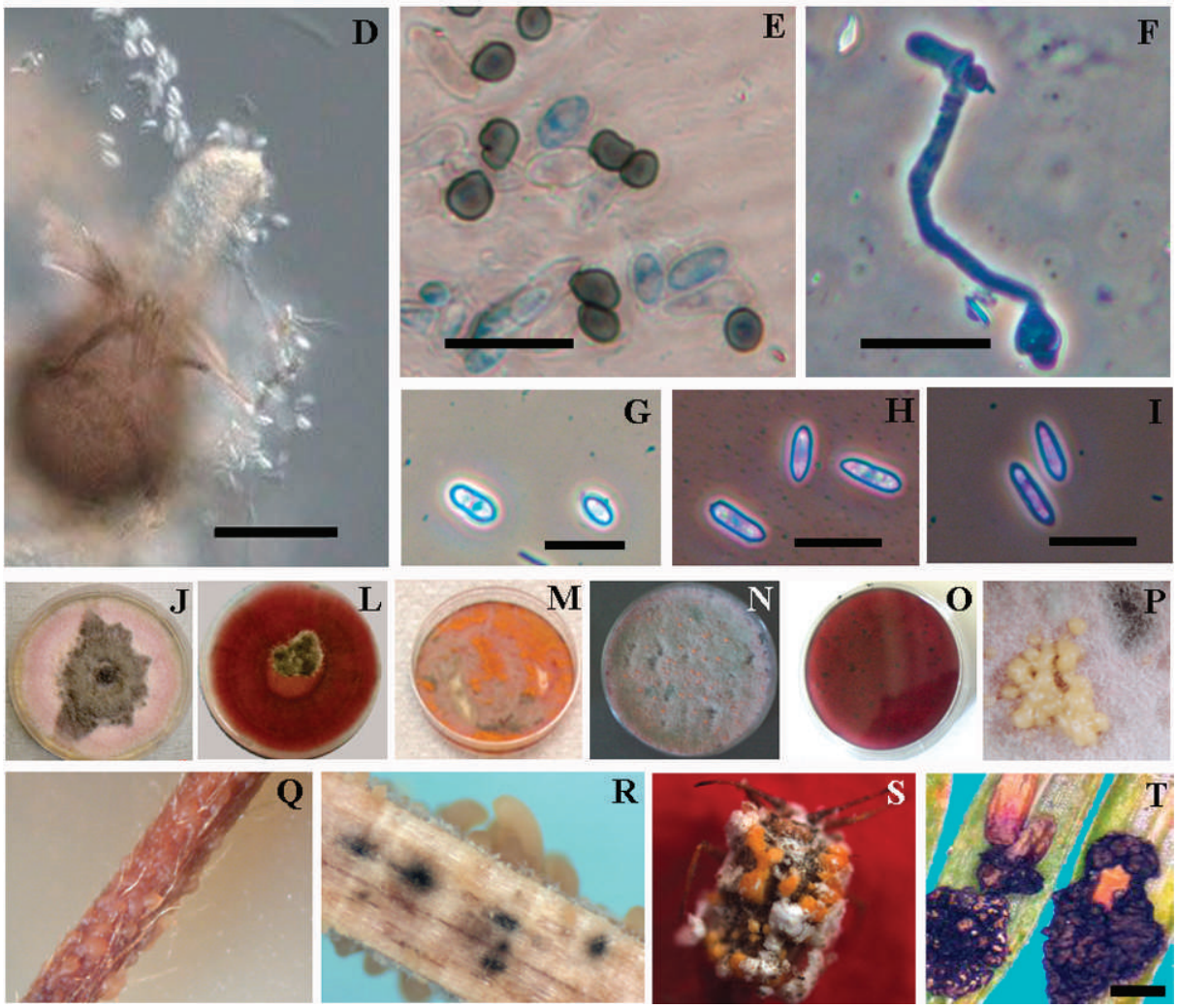

FIG. 1. A. Perithecia in planta from cross-fertile strains of Colletotrichum sp., ERL $\mathrm{E}_{1385} \times \mathrm{EHS}_{58}$. B. intact ascus. C. Free ascospores. D. Perithecia discharging ascospores. E. Appresoria of C.a. fioriniae strain $\mathrm{EHS}_{47}$, from epizootic site. F. Appressorium of C. gloeosporioides, strain $\mathrm{EMA}_{26}$, from Brazilian epizootic. G. Conidia from C. gloeosporioides, EMA 26 ; H. $\mathrm{ARSEF}_{4630}$. I. C.a. fioriniae, strain EHS48, from epizootic area. J-M. Morphological plasticity and overlapping phenotypes of C.a. fioriniae strains from epizootic localities. N. Top and O. Reverse of C.a. fioriniae strain $\mathrm{EHS}_{58}$ in PDA at 25 C. P. Conidia produced by C.a. fioriniae from epizootic site. Q. Strawberry stem from cross-fertile bioassay presenting profuse conidia masses. R. Birch toothpick from cross-fertile bioassay with conidia masses and sterile tridimensional structures. S. Adult $O$. praelonga infected with C. gloeosporioides $\mathrm{f}$. sp. ortheziidae (orange masses). Brazil. T. Adult F. externa with epizootic USA. Bars: $\mathrm{A}=200 \mu \mathrm{m} ; \mathrm{B}, \mathrm{C}, \mathrm{E}, \mathrm{F}=20 \mu \mathrm{m} ; \mathrm{D}=60 \mu \mathrm{m} ; \mathrm{G}-\mathrm{I}=15 \mu \mathrm{m}, \mathrm{T}=0.5 \mathrm{~mm}$

New England to western Ohio and Tennessee (Johnson and Lyon 1988, USDA Forest Service 2004, Lambdin et al 2005). Chemical and classical biological control approaches have not been successful in halting the spread of this pest. A rapid resurgence of scales after chemical treatments occurs in the next generation due to a density dependent feedback stimulated by lack of competition for resources and resulting in fecundity of the insect pest (McClure 1978a). Natural enemies of the Fiorinia scale (e.g. the aphelinid parasitoid, Encarsia citrina Craw [= Aspidiotiphagus citrinus Howard] [Hymenoptera: Apheli- nidae]) has shown inconsistent results in control rates due to lack of synchrony between the life cycles of both species (McClure 1978b).

Pathogens have long been known to play a major role in the population dynamics of many important forest pests. Economically the use of entomopathogenic fungi offers a unique alternative to a chemical control approach of an insect pest (Wraight et al 2001). Successful biological control efforts using fungi have been extensively reported (Keller et al 1997, Inglis et al 200, Meekes et al 2002). Moreover some insect pathogenic fungi are commercially used 
as myco-insecticides. The use of these fungi, under suitable environmental conditions, might be an important tool in inexpensively maintaining insect populations. In addition one of the major advantages of using pathogenic fungi is that they can establish and self perpetuate in the host, thus becoming a practical pest management option. The entomopathogen Entomophaga maimaiga Humber, Shimazu \& Soper was introduced in USA in the early 1900s, but it was not until 1989 that an epizootic was observed in populations of Lymantria dispar L. (Lepidoptera: Lymantriidae) in northeastern USA. This fungus now is considered a more effective pathogen than nuclear polyhedrosis virus, NPV (Hajek et al 1996, Dwyer et al 1998, Otvos 2004). If steps are taken to maintain or amplify the already established fungal epizootic in $F$. externa populations in northeastern USA it could ensure that the epizootic in $F$. externa would be sustained and natural control of this pest would continue.

$F$. externa together with the hemlock woolly adelgid, Adelges tsugae Annand (Hemiptera: Adelgidae), are causing a significant decline in what had been one of the dominant components of New England's forests for the past $8000 \mathrm{y}$ (Foster and Zebryk 1993, Danoff-Burg and Bird 2002, Snyder et al 2002). While no estimates of the economic damage done by these two pests have been published, a drastic decrease in hemlock forests has been quantified 1984-1994 (Royle and Lathrop 2002). Eastern hemlock plays a key role in maintaining balanced, stable forest ecosystems influencing long-term site quality and species dynamics (Mladenoff 1995). They play a particular important ecological role along streams, where their shade provides shelter, sustains aquatic ecosystems and creates unique microclimate for forest wildlife (Howe and Mossman 1995, Wydeven and Hay 1995, Crow 1995, Howard et al 2000). The effects caused by the progressive disappearance of eastern hemlock forests, which form a critical component of riverine systems in northeastern USA, would drastically alter these environments and likely place many species at risk.

Black sclerotial masses covering $80-100 \%$ of the bodies of $F$. externa were observed in northeastern hemlock forests 2002-2006 (FIG. 1T). Mortality of $F$. externa reached $36.8 \%$ in nature and $>90$ and $>55 \%$ in controlled laboratory experiments with $F$. externa crawlers and settlers respectively (Marcelino et al 2008a). Although the geographical origin of the epizootic is unknown it has been detected in 36 sites in New York, Connecticut, Pennsylvania and New Jersey.

The objective of this work was to characterize morphologically, biologically and molecularly the
Colletotrichum sp. isolated from $F$. externa and to compare it to selected plant pathogenic strains in the same genus.

\section{MATERIALS AND METHODS}

Morphological plasticity.-Morphological plasticity was determined for 26 pure cultures of Colletotrichum sp. isolated from F. externa collected in Bayberry Lane, Mohonk, Esopus and Ward Pound Ridge Reservation, New York, grown on potato dextrose agar media (PDA) maintained at 10, 15, 20 and $22 \mathrm{C}$. These fungal characteristics were monitored visually after $10 \mathrm{~d}$ : mycelium color, mycelium pigmentation, media pigmentation and presence and abundance of conidial masses. Monoconidial isolates and isolates derived from fungal suspensions in sterile distilled water were inoculated into $20 \mathrm{~mL}$ potato dextrose agar (PDA) medium and cultured in Petri dishes. A stage-mounted DC3001 micromanipulator (World Precision Instruments Inc., Sarasota, Florida) was used to obtain monoconidial isolates. The experiment was repeated three times for all isolates.

Sexual recombination.-Cross-fertile sexual recombination was attempted in vitro by testing all combinations of crosses between these $20 \mathrm{~d}$ old cultures: Colletotrichum sp. isolates from the same and different localities of the epizootic; the single known entomopathogenic strain of $C$. gloeosporioides from Brazil $\left(\mathrm{ARSEF}_{4360}\right)$; two plant pathogenic strains, $\mathrm{ERL}_{1395}$ and $\mathrm{ERL}_{1385}$, isolated from a golden delicious apple and a tulip tree (Liriodendron tulipifera L.) growing in the area of the epizootic (TABLE I).

In vitro crosses were done on minimal salts medium (MSM), according to the protocol by Guerber and Correll (2001). Petri dishes were sealed with parafilm. Plates were incubated at room temperature $(22 \pm 0.5 \mathrm{C})$ with two constant cool white fluorescent lights placed $1.2 \mathrm{~m}$ above the plates and four additional lights $2.5 \mathrm{~m}$ away on surrounding walls. Autoclaved birch (Betula sp.) toothpicks (Diamond Brand Inc., Minneapolis) and excised $2 \mathrm{~cm}$ long strawberry stems sterilized with propylene oxide were used as substrates to assess cross fertilization. Substrates were arranged in an $\mathrm{N}$ pattern. Mating plates were screened after $40 \mathrm{~d}$ to detect the presence of perithecia in the middle toothpick or stem, where the probability of self fertilization was reduced. The cross-fertilization experiment using toothpicks was repeated twice, whereas the one with strawberry stems was conducted once.

In planta sexual crossings were performed according to protocols from Cisar et al (1996), using 4.5 y old hemlock seedlings (Tsuga canadensis [L.] Carrière), 3 mo old bush snap bean (Phaseolus vulgaris L. var. Blue Lake 274) and 3 mo old strawberry plants (Fragaria $\times$ ananassa Duchesne var. Honeoye) to determine whether Colletotrichum sp. $\left(\mathrm{EHS}_{58}\right)$ obtained from $F$. externa and Colletotrichum sp. $\left(\mathrm{ERL}_{1385}\right)$ isolated from a tulip tree could self and/or cross fertilize. Strains of both fungi used in these experiments originated from an area of high incidence of the epizootic (Ward Pound Ridge Reservation, New York). Strain ERL 1385 was used because this Colletotrichum sp. was isolated repeatedly from tulip trees and because molecular data 
MyCOLOGIA

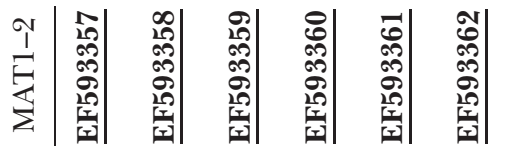

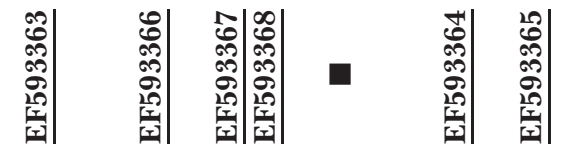
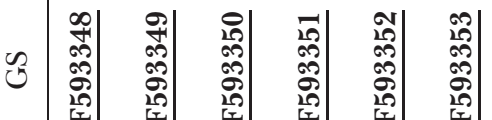

章|

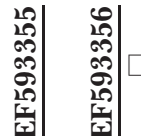

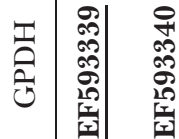
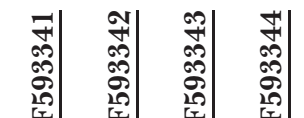

这莺

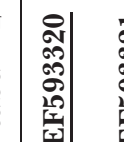

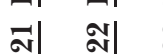

(1)

离

部

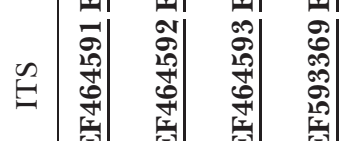

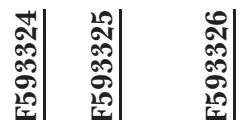

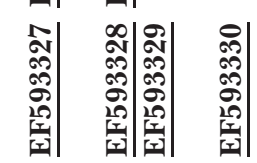

20.

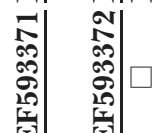

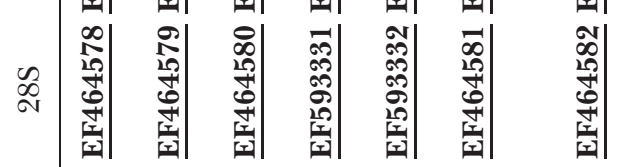

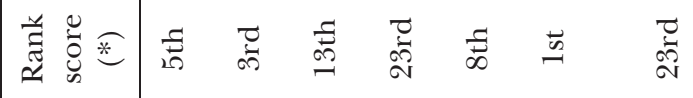

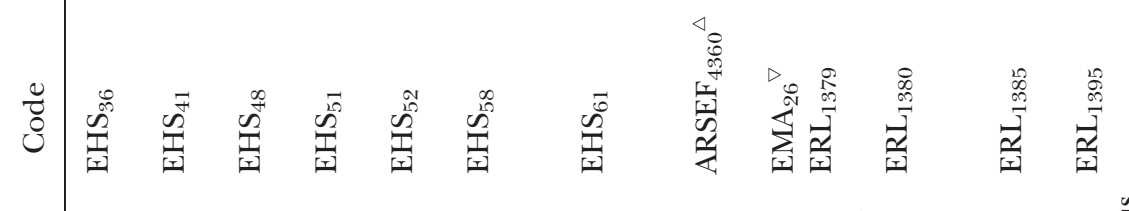

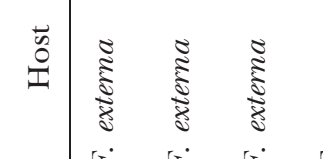

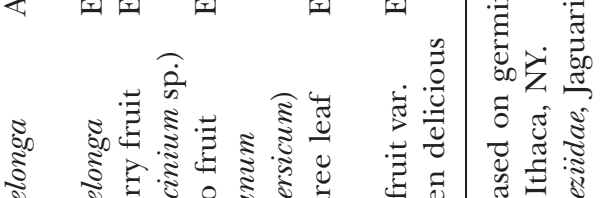

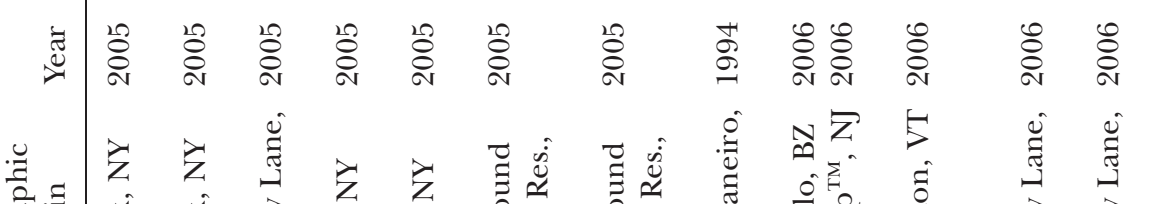
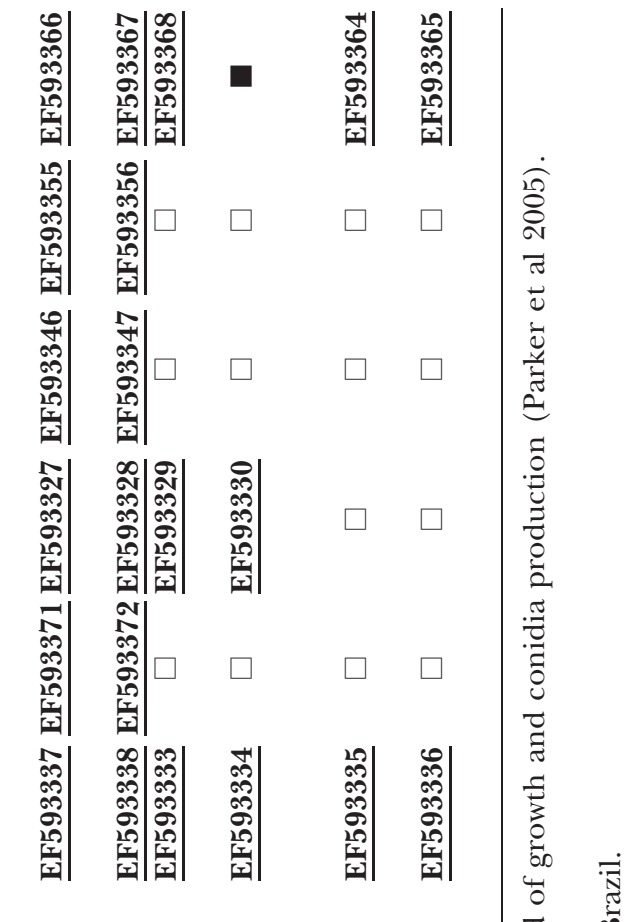

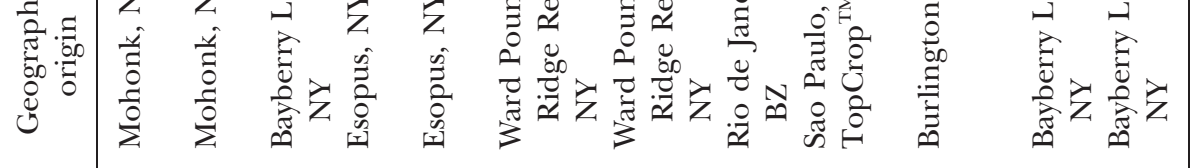

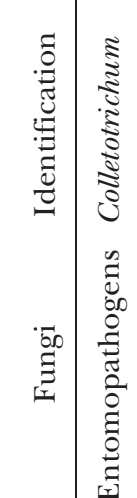

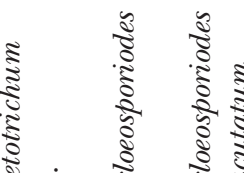

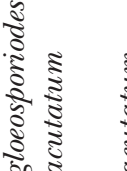
$\frac{2}{3}$

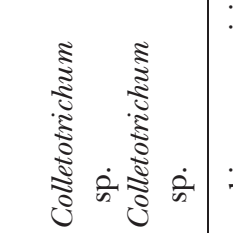

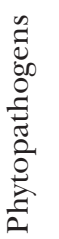

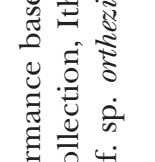

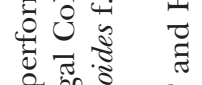

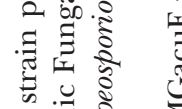


confirmed that it was identical to the Colletotrichum strain EHS $_{58}$ isolated from $F$. externa. Two parallel sets of plants were set up. The first set included six plants per species, while the second set included four. Plants were bruised individually with a sterile scalpel (four bruises/plant) and inoculated with $200 \mu \mathrm{L}$ of $10^{6}$ suspension of either Colletotrichum sp. $\mathrm{EHS}_{58}$ or Colletotrichum sp. ERL 1385 Inoculated plants were held in a dew chamber $(3.95 \mathrm{~m}$ high $\times 1.10 \mathrm{~m}$ wide $\times 1.10 \mathrm{~m}$ deep, built with $2.5 \mathrm{~cm}$ diam PVC pipe and covered with plastic) for $24 \mathrm{~h}$ at $22 \pm 1 \mathrm{C}$, according to protocols of TeBeest (1988), and placed in a greenhouse at $22 \mathrm{C}$ for $8 \mathrm{~d}$. Afterward the same bruises were inoculated with the alternate strain (i.e. $\mathrm{EHS}_{58}$ followed by $\mathrm{ERL}_{1385}$ or $\mathrm{ERL}_{1385}$ followed by $\mathrm{EHS}_{58}$, depending on the first strain initially inoculated). Re-inoculated plants again were held in the dew chamber $24 \mathrm{~h}$ then moved to the greenhouse. For the first set of plants (six replicates) sample stems were excised weekly, whereas for the second set of plants (four replicates) the stems were excised at 3 and 6 wk. A $2 \mathrm{~cm}$ sample was excised from each plant and placed in MSM medium with penicillin $(5 \mathrm{~mL} / \mathrm{l})$ and streptomycin $(12.5 \mathrm{~mL} / \mathrm{l})$ and maintained in a growth chamber at a 8:16 h photoperiod (L:D) and $22 \mathrm{C}$. They were examined for the presence of the teleomorph stage (Glomerella) weekly for a month. The experiment above was repeated using the bean plants and inoculated with $\mathrm{ERL}_{1385}$ and another entomopathogenic strain, $\mathrm{EHS}_{48}$ from Bayberry Lane, New York.

Measurements of fungal structures.-Conidial spores were harvested from $14 \mathrm{~d}$ old monoconidial PDA cultures of 26 Colletotrichum sp. isolated from the epizootic in USA and two Colletotrichum $\mathrm{f}$. sp. ortheziidae from the epizootic in Brazil. Spores were stained with cotton blue lactophenol to enhance contrast. Appresoria were produced on $1 \mathrm{~cm}$ diam strawberry leaf disks. A drop of culture suspension was placed on individual leaf disks. Samples were incubated for $24 \mathrm{~h}$ at $22 \mathrm{C}$ in Petri dishes lined with moist filter papers. Appresoria were removed from leaves using the Scotch ${ }^{\mathrm{TM}}$ tape print technique of Gouli et al (2005), stained with cotton blue lactophenol to enhance visualization and avoid plant tissue interference. Conidia and appresoria were viewed with a 40x phase-contrast Trinocular BH2 Olympus compound microscope and photographed with a CCD digital camera (Pixelink, Vitana Corp., Ottawa, Canada). Measurements of length and width were taken $\left(\mathrm{n}_{\text {conidia }}=\right.$ $1751 ; \mathrm{n}_{\text {appresoria }}=1387$ ), from which shape and elliptical form factors were calculated with the formulas below (Metamorph ${ }^{\circledR}$ software, Universal Imaging Corp., West Chester, Pennsylvania). Intact perithecia were removed from bean stems with a sterile insect pin and placed in a glass slide, submerged in a droplet of distilled water and mounted with a cover slide and photographed at 40x in an Olympus BX51 photomicroscope connected to an AxioCam HC camera (Carl Zeiss Inc., Oberkochen, Germany). Ascospores extruded from perithecia were viewed in distilled water and photographed using the same procedures. Length, width, area and shape were calculated for both perithecia $(n=40)$ and ascospores $(n=119)$. In addition the elliptical form factor was calculated for the perithecia. These values were calculated with Metamorph ${ }^{\circledR}$ software:

$$
\begin{aligned}
& \text { Spore length }=\frac{1}{4}\left(\mathrm{P}+\sqrt{\mathrm{P}^{2}-16 \mathrm{~A}}\right) \\
& \text { Spore breadth }=\frac{1}{4}\left(\mathrm{P}-\sqrt{\mathrm{P}^{2}-16 \mathrm{~A}}\right) \\
& \text { Shape Factor }=\frac{4 \pi \mathrm{A}}{\mathrm{P}^{2}} \quad(\text { Circumference }=1) \\
& \text { Elliptical Form Factor }=\frac{\text { Length }}{\text { Breadth }} \\
& \text { (Ratio of object's breadth to its length) } \\
& P=\text { Perimeter; A }=\text { Area } \\
& \text { Appressorium length }=\text { Longest chord through the } \\
& \text { object } \\
& \text { Appressorium width }=\text { Horizontal dimension of the } \\
& \text { object } \\
& \text { Adapted from Metamorph }{ }^{\circledR} \text { (2003) }
\end{aligned}
$$
object object

Statistical analysis. - The Student-Newman-Kuels test $(\alpha=$ 0.05 ) was used to identify significant difference between the morphological parameters obtained for the isolates tested. Statistical analysis was performed with SAS $^{\circledR}$ (SAS Institute 1990) software.

Phylogenetic analyses. - Six pure strains of Colletotrichum sp. obtained from $F$. externa were chosen for molecular analysis based on data for germination, growth rate and conidial production (Parker et al 2005). The rDNA from these entomopathogenic and phytopathogenic strains also was sequenced: C. gloeosporiodes. f. sp. ortheziidae ( $\left.\mathrm{ARSEF}_{4360}\right)$ from the USDA-ARS collection of entomopathogenic fungal cultures; C. gloeosporiodes. f. sp. ortheziidae from EMBRAPA, Brazil $\left(\mathrm{EMA}_{26}\right)$; and C. acutatum, $\mathrm{ERL}_{1379}$ and $\mathrm{ERL}_{1380}$ (TABLE I).

These genes were used to characterize selected isolates: D1/D2 region of the 28S ribosomal DNA, with primers NL1 and NL4 (O'Donnell 1992, 1993) commonly used for phylogenetic analysis at the genus level and above (Hillis and Dixon 1991); internal transcribed spacers ITS1 and ITS2 with primers ITS1 and ITS4 (White et al 1990) for within-species differentiation (Afanador-Kafuri et al 2003); introns of glyceraldehyde-3-phosphate dehydrogenase $(\mathrm{GPDH})$, associated with the infection process of Colletotrichum (Wei et al 2004), with primers GDF1 and GDR1 (Templeton et al 1992); glutamine synthetase protein (GS), highly expressed during pathogenesis with primers GSF1 and GSR1 (Stephenson et al 1997); and newly constructed internal primers GLUintF1 (5'-AGCCGGAAGTCGGAGA CATCCCG- $3^{\prime}$ ) and GLUintR2 (5'-CGTTGCTGTTCT CCACGCAAT- $\left.3^{\prime}\right)$. The $\beta$-tubulin 2 protein encoding gene, used to distinguish fungi at deep phylogenetic levels (Thon and Royse 1999, Lubbe et al 2004), was amplified with primers TB5 and TB6 (Pannacione and Hanau 1990). The mating-type gene (MAT 1-2) from the high mobility box (HMG), used to study fungal biology (Turgeon 1998), was 
amplified with primers HMGacuF and HMGacuR (Du et al 2005). A genetic characterization of representative Colletotrichum sp. isolates from the different regions of the epizootic, the Brazilian entomopathogenic C. gloeosporioides $\left(\mathrm{ARSEF}_{4360}\right)$ and the phytopathogenic C. acutatum $\left(\mathrm{ERL}_{1379)}\right)$ was conducted with randomly amplified polymorphic DNA (RAPD), with primers derived from repeated ${\text { sequences } \text { GACA }_{(4)} \text { (Weising et al 1989), GACAC }}_{(3)}$ (Gupta and Filner 1991) and ACTG $_{(4)}$ (Freeman et al 1995).

DNA was extracted from 1 wk old cultures with the Power Soil ${ }^{\mathrm{TM}}$ DNA kit (MoBio Laboratories Inc., Carlsbad, California) and the FastPrep ${ }^{\mathrm{TM}}$ FP120 machine (Thermo Savant, Holbrook, New York). Samples were shaken 5 min at $5.5 \mathrm{~m} / \mathrm{s}$ to break open fungal cell walls. This modification was made to the Power Soil ${ }^{\mathrm{TM}}$ DNA kit: DNA was eluted with $100 \mu \mathrm{L}$ of diluted elution buffer AE from QIAGEN (1:15) containing $10 \mathrm{mM}$ of Tris and $0.5 \mathrm{mM}$ of EDTA and concentrated down to $20 \mu \mathrm{L}$ with a speed vacuum (Eppendorf Centrifuge 5415 C, Vaudaux, Schönenbuch, Switzerland).

Polymerase chain reaction (PCR) was performed with Ready-To-Go PCR beads (Amersham Biosciences Inc., Piscataway, New Jersey). Genes were amplified with this protocol: initial denaturation at $95 \mathrm{C}$ for $2 \mathrm{~min}$, followed by 30 cycles of $95 \mathrm{C}$ for $30 \mathrm{~s}$ (denaturation), $50 \mathrm{C}$ for $30 \mathrm{~s}$ (annealing) and $72 \mathrm{C}$ for $1 \mathrm{~min}$ (elongation) with changes in annealing temperature, ITS (52 C), GPDH (54 C), $\beta$ tubulin $2(65 \mathrm{C})$ and MAT 1-2 (55 C). RAPD were amplified with Freeman et al (1995) protocols. PCR products were purified with the QIAGEN QIAquick ${ }^{\circledR}$ PCR purification kit (Valencia, California) or Princeton Separations Centri Spin ${ }^{\mathrm{TM}}$ columns (Adelphia, New Jersey). DNA was stored at $4 \mathrm{C}$. PCR products were sequenced with BigDye v1 and BigDye v3 terminator cycle sequencing kit (Applied Biosystems, Foster City, California) with this protocol: initial denaturation at $95 \mathrm{C}$ for $3 \mathrm{~min}$, followed by 30 cycles of $95 \mathrm{C}$ for $10 \mathrm{~s}$ (denaturation), $50 \mathrm{C}$ for $5 \mathrm{~s}$ (annealing) and $60 \mathrm{C}$ for $2 \mathrm{~min}$ (elongation).

Sequencing reactions were run on a $3130 \times 1$ Genetic Analyzer (Applied Biosystem, Foster City, California). Chromatograms were edited and contiguous sequences were generated with Sequencher ${ }^{\mathrm{TM}}$ (Gene Codes Corp., Ann Arbor, Michigan). Sequences were analyzed with related sequences obtained from GenBank ${ }^{\circledR}$ (Templeton et al 1992; Dufresne 1997; Nirenberg et al 2002, Lubbe et al 2004, Du et al 2005, Talhinhas et al 2002, 2005) with the exception of the majority of GPDH and GS sequences, which were not available in GenBank and were transcribed manually from Liu (2002). Introns were aligned individually with the aid of Clustal W (Chenna et al 2003) and retrieved with Jalview software (Clamp et al 2004). Exons were aligned separately based on their respective protein sequences with McClade (Maddison and Maddison 1992). Because rDNA analyses have not resolved the phylogenetic relationships within Colletotrichum spp. (Crouch et al 2005, Du et al 2005) outgroups were chosen based on their genetic distance to strains used in the phylogenetic analysis. These outgroup taxa were used: C. malvarum (Z18981) for the D1/D2 domain of the $28 \mathrm{~S}$ gene; C. malvarum (949C3E55) and $C$. gloeosporioides (9E1589A5) for the GS gene; C. kahawae
(AY376588) and C. gloeosporioides (AY376582); Glomerella cingulata (M93427) and G. cingulata (7BDBDAF86) for the GPDH gene; $C$. coccodes (AY3766528) for the ITS region; and C. gloeosporioides (DQ002823) for the HMG at the MAT1-2 gene.

Phylogenetic trees were estimated with maximum parsimony as implemented in PAUP 4.0b10 (Swofford 2002). One representative isolate was included in the analysis because the genomic sequences of Colletotrichum sp. from all the regions of the epizootic were identical for all genes analyzed. Sequence gaps were treated as missing data. Bootstrap analysis was performed with 1000 bootstrap replications with 30 random additions of taxa. Multiple equally parsimonious trees were combined into a single strict-consensus tree. Only bootstrap values above 70 were included in the final trees. Sequences in this analysis were deposited in GenBank (accession numbers are included in TABLE I). The sequence alignment for all the genes sequenced and respective phylogenetic trees also will be deposited in TreeBase databases (accession numbers to be assigned). Primers were excluded from published sequences and sequence alignments.

\section{RESULTS}

Morphological plasticity.-Isolates used in this study showed a wide range of morphological variability often presenting several phenotypes as sectors within a colony (FIG. 1J-N) for both single-spore and suspension-derived isolates (TABLE II).

Mycelium ranged from gray or black when cultured on PDA at 10 and $15 \mathrm{C}$ to pink or orange at 20 and 25 C. Multiple colors were present at times in the mycelia and the media (FIG. 1M). Chromogenic media pigmentation, typical of $C$. acutatum, was observed at 20 and $25 \mathrm{C}$ in most of the isolates with gray and/or pink mycelium (FIG. 1O). Single-spore isolates showed a stronger black pigment in the media at $10 \mathrm{C}$ than the suspension-derived isolates, which turned gray at $10 \mathrm{C}$. Only isolates $\mathrm{EHS}_{46}, \mathrm{EHS}_{50}$ and $\mathrm{EHS}_{51}$ produced orange mycelium consistently at all test temperatures. For the remaining isolates gray mycelium pigment was observed at all temperatures. Aerial mycelium was seldom observed at all temperatures and in all isolates. Conidial masses (FIG. 1P) were not observed on single-spore cultures but did occur in cultures derived from suspension at $20 \mathrm{C}$ (TABLE II). Statistical analysis was not performed on these data because only the presence or absence of pigment was recorded. In general isolates grown at $10 \mathrm{C}$ or $15 \mathrm{C}$ (both single spore or suspension derived) produced gray mycelium, with sectors of other colors. In contrast at $25 \mathrm{C}$ most isolates produced an equal combination of gray and pink mycelia with local sectors of other colors. Single-spore isolates were more uniform in color although color differences were common at 15 and $25 \mathrm{C}$. 
TABLE II. Morphological plasticity in Colletotrichum sp. isolated in epizootic areas

\begin{tabular}{|c|c|c|c|c|c|c|c|c|c|c|c|c|c|c|c|c|}
\hline \multirow[b]{4}{*}{ Temp. } & \multicolumn{16}{|c|}{ Inoculum source - SUSPENSION } \\
\hline & \multicolumn{16}{|c|}{ Character state } \\
\hline & \multicolumn{6}{|c|}{ Fungal pigmentation $\diamond$} & \multicolumn{2}{|c|}{ Conidia } & \multicolumn{2}{|c|}{$\begin{array}{l}\text { Mycelium } \\
\text { morphology }\end{array}$} & \multicolumn{6}{|c|}{ Media $^{\diamond}$ pigmentation } \\
\hline & G & $\mathrm{O}$ & $\mathrm{W}$ & $\mathrm{P}$ & $\mathrm{R}$ & B & $\mathrm{C}$ & $\mathrm{C}+$ & $\mathrm{S}$ & $\mathrm{A}$ & B & $\mathrm{O}$ & G & $\mathrm{P}$ & Cr. & $\mathrm{W}$ \\
\hline $10 \mathrm{C}$ & 84 & 21.3 & - & - & - & - & - & - & 98.6 & 1.3 & 1.4 & 17.3 & 81.3 & - & - & - \\
\hline $15 \mathrm{C}$ & 86.6 & 32 & 1.3 & - & - & - & - & 8 & 89.4 & 10.6 & 4 & 25.4 & 76 & 16 & 2.6 & - \\
\hline $20 \mathrm{C}$ & 85.3 & 37.3 & - & 32 & - & - & - & 16 & 97.3 & 2.7 & 16 & 49.4 & 42.6 & 53.4 & 34.7 & - \\
\hline \multirow[t]{2}{*}{$25 \mathrm{C}$} & 29.4 & 18.6 & 1.3 & 80 & 4 & & 6.7 & 9.4 & 89.4 & 10.6 & - & 20 & 13.3 & 42.6 & 42.6 & - \\
\hline & \multicolumn{16}{|c|}{ Inoculum source - SINGLE SPORE } \\
\hline Temp. & G & $\mathrm{O}$ & $\mathrm{W}$ & $\mathrm{P}$ & $\mathrm{R}$ & B & $\mathrm{C}$ & $\mathrm{C}+$ & $\mathrm{S}$ & $\mathrm{A}$ & B & $\mathrm{O}$ & G & $\mathrm{P}$ & Cr. & W \\
\hline $10 \mathrm{C}$ & 90.6 & 10.6 & - & - & - & 13.3 & - & - & 94.6 & 5.4 & 89.3 & 62.6 & 10.6 & - & - & 92 \\
\hline $15 \mathrm{C}$ & 100 & 5.3 & 5.3 & - & - & 2.6 & - & - & 90.7 & 9.3 & 16 & 40 & 1.3 & 53.3 & - & 41.3 \\
\hline $20 \mathrm{C}$ & 92 & 5.3 & - & 72 & - & - & - & - & 89.4 & 10.6 & 15.5 & 5.3 & 5.3 & 22.6 & 61.3 & 5.3 \\
\hline $25 \mathrm{C}$ & 92 & 33.4 & 8 & 65.3 & - & - & - & - & 98.7 & 1.3 & 2.6 & 4 & 2.6 & - & 97.3 & - \\
\hline
\end{tabular}

$\diamond$ All values are percentage of total number of plates presenting the character state $(n=78,3$ replicates were tested for each temperature).

Conidia masses: scattered (C), uniformly distributed (C+).

Mycelium morphology: aerial (A), superficial (S.

Mycelium and medium pigmentation: black (B); gray (G), Aerial dense gray (G+), Orange (O), Pink (P), Red (R), White (W), Chromogenic (Cr.).

Sexual recombination. - In vitro crossings were partially successful when using toothpicks as a substratum (TABLE III). Cross-fertile recombination on toothpicks appeared to be incomplete in both repetitions of the experiment although tridimensional sterile structures were observed together with profuse conidial masses (FIG. 1R) especially on diagonally placed toothpicks (N). For $\mathrm{EHS}_{48} 79 \%$ of the attempted crosses resulted in the production of these sterile structures. The phytopathogenic isolate $\left(\mathrm{ERL}_{1395}\right)$ did not produce sterile structures in any crosses with the epizootic strains. The tulip tree isolate $\left(\mathrm{ERL}_{1385}\right)$ produced sterile structures in $64 \%$ of the attempted crosses. The number of sterile structures was observed to be higher in crosses with isolates from different geographic origins. The crossfertile bioassay using strawberry stems as a substratum produced profuse conidial masses (FIG. 1Q).

In planta cross fertilizations with strawberries and beans as substratum were successful only in the latter. At $4 \mathrm{wk}$ and after $1 \mathrm{wk}$ from excision from the plant, profuse numbers of perithecia were observed in selffertile cross of $\mathrm{EHS}_{58} \times \mathrm{EHS}_{58}$ The cross-fertile $\mathrm{ERL}_{1385} \times \mathrm{EHS}_{58}$ produced perithecia after $5 \mathrm{wk}$ in planta (FIG. 1A) and after $1 \mathrm{wk}$ on excised stems in Petri dishes (FIG. 1D). Perithecia were produced in planta in two of the stem cuts in one of the experimental bean plants and in vitro in two bean stems cultured in MSM for $1 \mathrm{wk}$. Perithecia were not produced in a repeated experiment on beans. However the perithecia produced in the bean stems in the first experiment were fertile, generating asci containing eight visible ascospores (FIG. 1B).

Measurement of fungal structures. - Wide ranges in the dimensions of the different propagules were measured. The mean conidial length of the 26 entomopathogen Colletotrichum sp. strains (FIG. 1I) was significantly smaller $(5.61-8.57 \times 2.73-4.22 \mu \mathrm{m})$ than the reported means for $C$. acutatum (TABLE IV). The ranges of means for Brazilian isolates of $C$. gloeosporioides f. sp. ortheziidae, EMA 26 (FIG. 1G) and AR$\mathrm{SEF}_{4360}$ (FIG. $\left.1 \mathrm{H}\right)$ were $10.35 \times 2.50 \mu \mathrm{m}$ and $11.88 \times$ $2.37 \mu \mathrm{m}$ respectively. These ranges were significantly lower than those obtained for the Colletotrichum sp. isolates from sampled epizootic areas, with the exception of isolates $\mathrm{EHS}_{51}, \mathrm{EHS}_{52}$ and $\mathrm{EHS}_{56}$, which were within the range of widths for $\mathrm{EMA}_{26}$ Conidia of C. gloeosporioides $\mathrm{f}$. sp. ortheziidae $\left(\mathrm{EHS}_{35}\right)$ were more oblong than the entomopathogenic Colletotrichum sp. from $F$. externa. In addition the range of means for $C$. gloeosporioides $\mathrm{f}$. sp. ortheziidae also was smaller than that reported for C. gloeosporioides. Only one strain of Colletotrichum sp., $\mathrm{EHS}_{41}$, was significantly different from all the other strains with respect to the spore area (TABLE IV).

The mean appresoria size (length $\times$ width) of the entomopathogenic Colletotrichum sp. (FIG. 1E), 


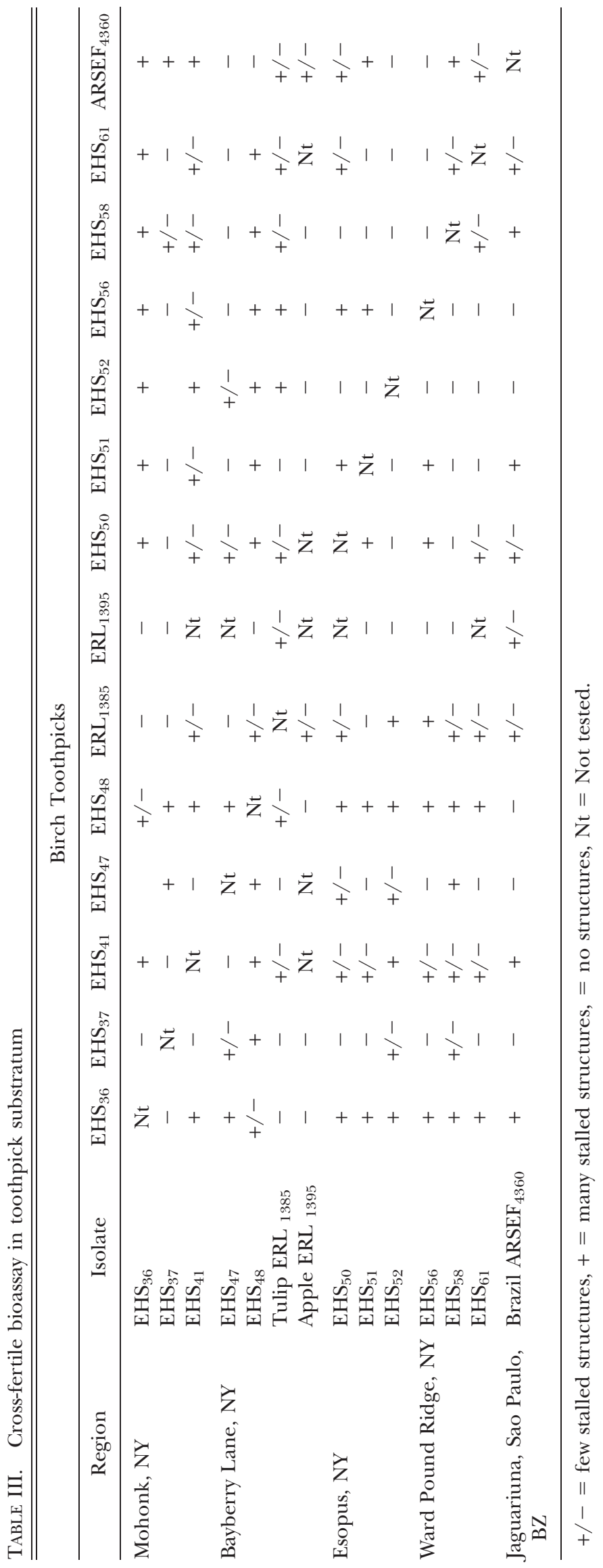




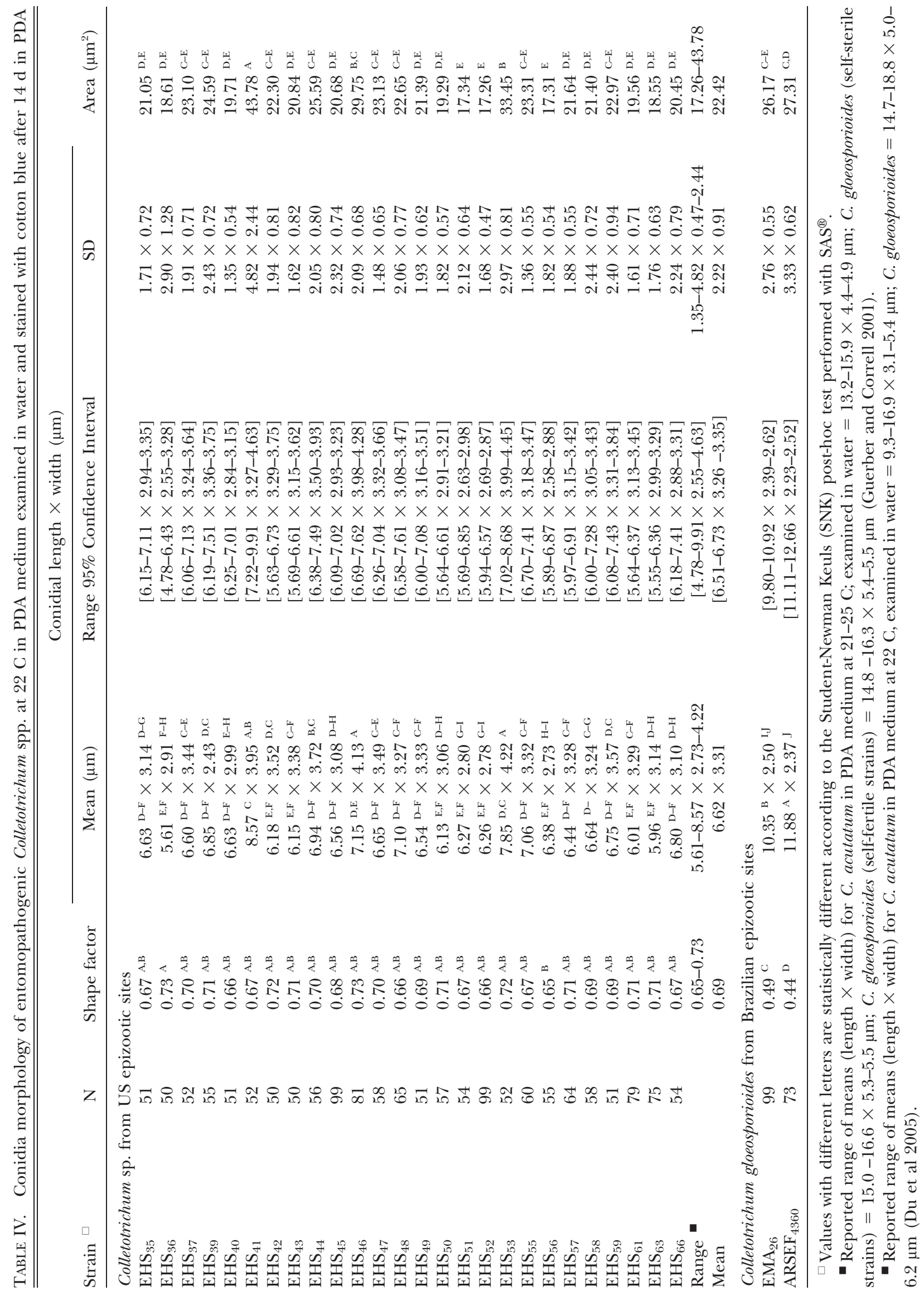


ranged from $6.35-7.85 \times 5.58-6.85 \mu \mathrm{m}$ and was similar to the reported range for $C$. acutatum (TABLE V). The appresoria obtained from C. gloeosporioides $\mathrm{f}$. sp. ortheziidae $\mathrm{EMA}_{26}$ (FIG. 1F), ranged from $8.11 \times 6.90 \mu \mathrm{m}$ and were also within the range for this species. Colletotrichum gloeosporioides, AR$\mathrm{SEF}_{4360}$, did not produce appresoria after numerous attempts on strawberry leaves, poinsettia leaves, Euphorbia pulcherrima and Citrus sp. leaves and fruit of mango, Mangifera sp. Although we found significant differences among isolates in appresoria shape, they fell within the reported ranges in most cases. An average shape factor of $0.74-0.85 \mu \mathrm{m}$ was calculated for Colletotrichum sp. (spherical $=1$ ) and 0.71 in $\mathrm{EMA}_{36}$. The spore area for the 26 Colletotrichum strains and two C. gloeosporioides f. sp. ortheziidae strains were identical statistically (TABLE V). Perithecia obtained from cross-fertile strains on plant stems after $7 \mathrm{~d}$ on MSM averaged $115.39 \times 108.83 \mu \mathrm{m}$, which was not within the reported range of Glomerella acutata. However perithecia obtained directly from stems (in planta) averaged $198.68 \times 183.75 \mu \mathrm{m}$, which is within the reported range for G. acutata. Perithecia retrieved in planta and from stems in MSM media were different statistically for length and width, shape and area $(P<0.05)$ (TABLE VI).

No ovoid perithecia were found among specimens retrieved from plant stems, whereas in Petri dish cultures $21 \%$ of 26 perithecia were ovoid. The ratio of perithecium breadth to length (elliptical factor) was not statistically different for perithecia in planta and on MSM. The length was greater than the width, with a more marked difference in the perithecia from MSM. The area of the perithecia produced in planta $\left(32211.60 \mu \mathrm{m}^{2}\right)$ was significantly different from those produced on MSM $\left(8639.28 \mu \mathrm{m}^{2}\right)$. Ascospores discharged from all perithecia measured were smaller than those reported for G. acutata (TABLE VI). However differences in area were found between ascospores from perithecia in planta (FIG. 1C), $28.30 \mu \mathrm{m}^{2}$, and those produced on stems and cultured on MSM $\left(39.29 \mu \mathrm{m}^{2}\right)$. These differences also were found in the shape factor (TABLE VII).

Molecular analysis. - A RAPD analysis of seven representative isolates of Colletotrichum sp. from the epizootic and a single phytopathogenic C. acutatum isolated from blueberry $\left(\mathrm{ERL}_{1379}\right)$ showed identical band patterns (FIG. 2). However some genetic variation was observed between the strains of Colletotrichum from the epizootic area in northeastern USA and the Colletotrichum sp. from the entomopathogenic $C$. gloeosporioides collected in Brazil ( $\left.\mathrm{ARSEF}_{4360}\right)$.

We sequenced six genes from seven strains of Colletotrichum isolated from the $F$. externa epizootic and two C. gloeosporioides f. sp. ortheziidae strains from the epizootic in Brazil. These genes comprise a total of 3121 base pairs. Parsimony informative characters for the respective genes in the analysis were: GPDH (72.1\%); HMG at the MAT1-2 (56.6\%); GS (34.6\%); $\beta$-tubulin (26.2\%); ITS (16.8\%) and D1/D2 region of the 28S rDNA (3.4\%). Colletotrichum and C. gloeosporioides nucleotide sequences obtained for the six genes were compared individually with related sequences from GenBank using BLAST. A subset of sequences with similarity at or above $90 \%$ were retrieved from GenBank and incorporated in the dataset used for the phylogenetic analysis included herein. Colletotrichum isolated from F. externa and C. gloeosporioides isolated from $O$. praelonga were found to be most similar to known representative phytopathogenic C. acutatum species. For the ITS sequences Colletotrichum from $F$. externa was identical to C. lupini (FIG. 3). The mean character difference for the respective genes used in the analysis between the two entomopathogenic Colletotrichum spp., listed in decreasing order, is GPDH (8.4\%), GS (5.9\%), $\beta$-tubulin2 (4.1\%), HMG at MAT1-1 (3.7\%), ITS (1.3\%) and the D1/D2 region of the $28 \mathrm{~S}$ rDNA $(0.36 \%)$. We could not analyze a concatenated dataset of all the genes because sequences are not available for the same taxa in all genes. With the exception of the two ribosomal sequences, ITS and the 28S, the analysis from all other genes analyzed show strong support for the placement of the two entomopathogenic forms within a monophyletic $C$. acutatum, despite the different taxa used for each gene (Figs. 4, 5, 6). The GPDH gene showed the greatest divergence between the $F$. externa-derived Colletotrichum and C. gloeosporioides from $O$. praelonga, despite having sequenced 248 base pairs (FIG. 5). GPDH had the largest number of well supported branches, whereas $28 \mathrm{~S}$ had the least.

\section{TAXONOMY}

Glomerella acutata J.C. Guerber \& J.C. Correll var. fioriniae J.A.P. Marcelino \& S. Gouli var. nov. (anamorph: a var. of Colletotrichum acutatum Simmonds ex Simmonds).

Varietas haec ab Glomerella acutata differt in Fiorinia externa.

Etymology. From the Latin differt in = "differs in being parasitic on".

Perithecia in planta globose to ampulliform, more frequently ampulliform, $198.68 \times 183.75 \mu \mathrm{m}$ (length $\times$ width). Perithecia in vitro varying from ampulliform, globose and ovoid, mainly ampulliform or globose, $115.39 \times 108.83 \mu \mathrm{m}$. All perithecia ostiolate, dark brown becoming ferruginous when observed under light, with setaceous hairs in the ostiole. 


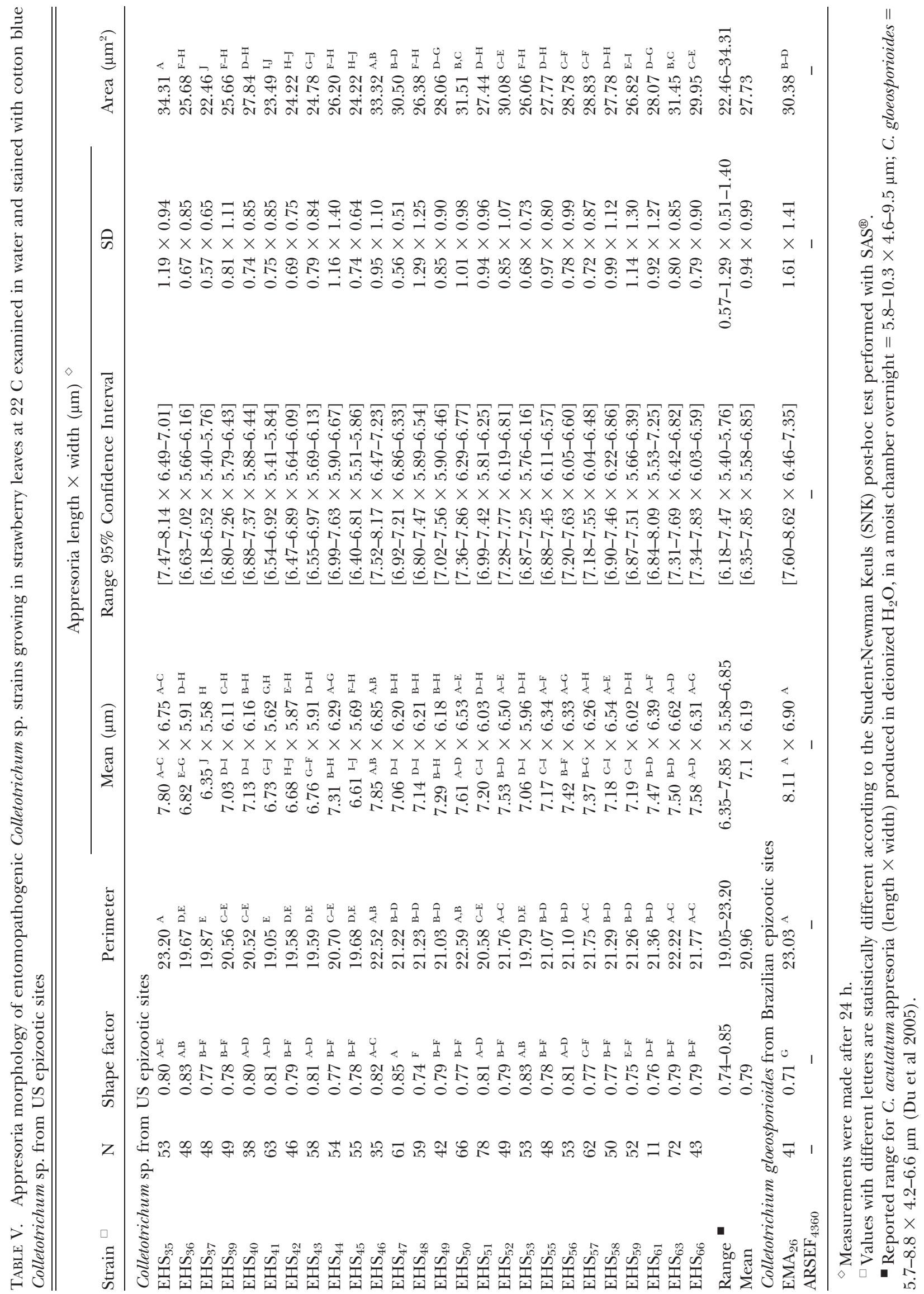



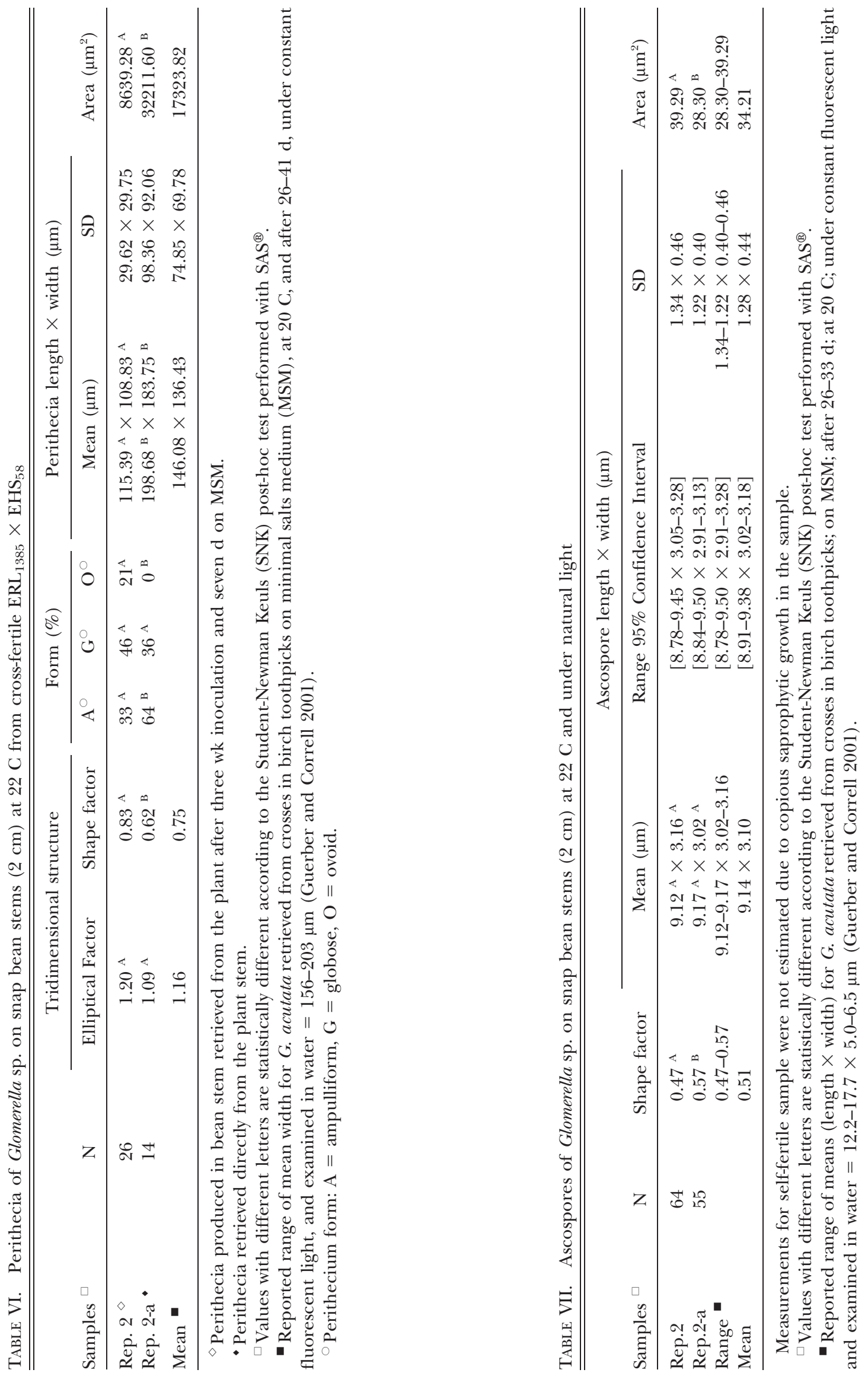


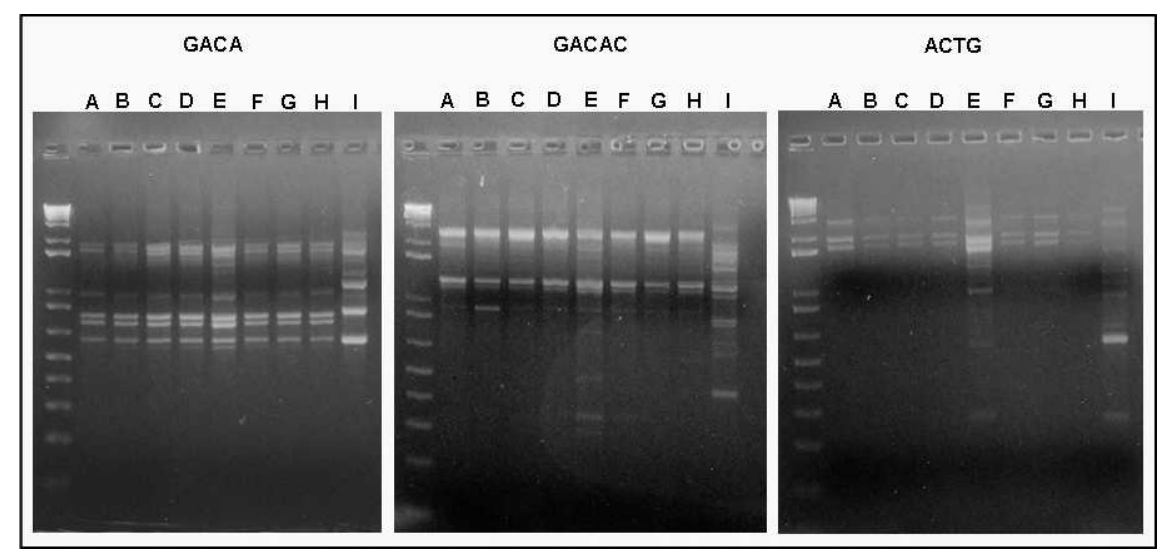

FIG. 2. Random amplified polymorphic DNA (RAPD) for C.a. fioriniae strains from different geographic localities within the epizootic area. A. EHS $\mathrm{EH}_{36}$. B. EHS $\mathrm{EH}_{41}$. C. EHS 48. D. EHS $\mathrm{EH}_{51}$ E. EHS $\mathrm{EH}_{52}$. F. EHS $\mathrm{EH}_{58}$ G. EHS 61 . H. From a phytopathogenic C. acutatum from blueberry, ERL 1379 . I. From the Brazilian entomopathogenic C. gloeosporioides f. sp. ortheziidae $\mathrm{ARSEF}_{4360}$.

Ostiole beaked in planta and papilliform or beaked in vitro, generally beaked. Neck soft brown or white, areolate on the outside. Asci 8-spored, clavate, attached by a short pedicel. Ascospores generally straight or fusiform with rounded apices, 8.84$(9.50) \times 2.91-(3.13) \mu \mathrm{m}$ in planta and 8.78-(9.45) $\times 3.05-(3.28) \mu \mathrm{m}$ in vitro, 1-celled, overlapping biseriate, accumulating around the ostiole when discharged from perithecia. Conidial stage Colletotrichum acutatum var. fioriniae J.A.P. Marcelino \& S. Gouli var. nov. Similar to Colletotrichum acutatum but differing in its pathogenicity on Fiorinia externa Ferris (Hemiptera: Coccoidea). Anamorph colonies presenting a wide morphological variability, often with several phenotypes as sectors within a colony, in both single-spore and suspension derived isolates cultured in PDA at constant 0:24 h photoperiod (L:D) and 15, 20, 25 C. Mycelium color at $10 \mathrm{C}$ was gray, whereas at higher temperatures several colors (black, gray, orange, pink, red, white) within a colony were present in mycelium and media. Superficial and aerial mycelia were both observed within a colony, more often superficial. Pink mycelium and chromogenic media pigmentation were abundant at 20 and 25 C. Conidial masses were observed only in suspension derived isolates. Scattered and often abundant conidiomata were observed at $25 \mathrm{C}$. Single-spore isolates were more uniform in color although color differences were common at 15 and $25 \mathrm{C}$.

HOLOTYPE: United States, Ward Pound Ridge Reserve, New York, from mummified adult Fiorinia externa insects, 2005, J. Marcelino \& S. Gouli; deposited at the University of Vermont, Department of Plant and Soil Science, Entomology Research Laboratory (ERL), Worldwide Collection of Entomopathogenic Fungi, Burlington, Vermont as liquid-preserved perithecia (90\% ethanol) produced by crossing Colletotrichum acutatum var. fiorinia strains $\mathrm{EHS}_{58} \times \mathrm{EHS}_{58}$ as well as mature mycelium of strain
EHS $_{58}$ in PDA agar cubes. PARATYPES: deposited at the University of Vermont, ERL, Worldwide Collection of Entomopathogenic Fungi, Burlington, Vermont, as mature mycelium (2 wk old) in PDA agar cubes $\left(1 \mathrm{~cm}^{2}\right)$ allocated in cryogenic vials (eight replicates) containing $10 \%$ glycerol, in permanent long storage $(-80 \mathrm{C})$. United States, Mohonk Preserve, Ulster, New York (VT - EHS 36 to $\mathrm{EHS}_{46}$ and EHS $_{66}$ ); United States, Bayberry Lane, Westchester, New York (VT - $\mathrm{EHS}_{47}$ and $\mathrm{EHS}_{48}$ ); United States, Hemlock Ridge, Ulster, New York (VT - $\mathrm{EHS}_{49}$ to $\mathrm{EHS}_{55}$ ); Ward Pound Ridge Reserve, Westchester, New York (VT - EHS ${ }_{56}$ to $\mathrm{EHS}_{64}$ ).

Remarks. Anamorph form associated with an epizootic in Fiorinia externa scale insects within New York, Pennsylvania, Connecticut and New Jersey. Parasitic on Fiorinia externa and endophytic in 28 species of plants in all strata of hemlock forests where epizootic occurs. Sample insects of mummified Fiorina externa were surface sterilized with $0.1 \% \mathrm{NaOCl}$ for $8 \mathrm{~s}$. Fungal strains were cultured in PDA with antibiotics (streptomycin, $12.5 \mathrm{~mL} / 1$ and penicillin, $5 \mathrm{~mL} / \mathrm{l}$ ) and singlespored in PDA a posteriori.

\section{DISCUSSION}

The work herein reports on the occurrence of Colletotrichum acutatum var. fioriniae isolated from F. externa in 36 localities in New York, Pennsylvania, Connecticut and New Jersey. This fungus also was found endophytically in the majority of plants tested in the sampled areas (Marcelino et al 2008b).

Twenty-six entomopathogenic isolates of Colletotrichum sp. obtained from $F$. externa, originating from four different geographic localities of the epizootic, were characterized morphologically to determine whether they were the same strain and to compare them to known Colletotrichum species to assess their closest relative. Included in this analysis is the only 


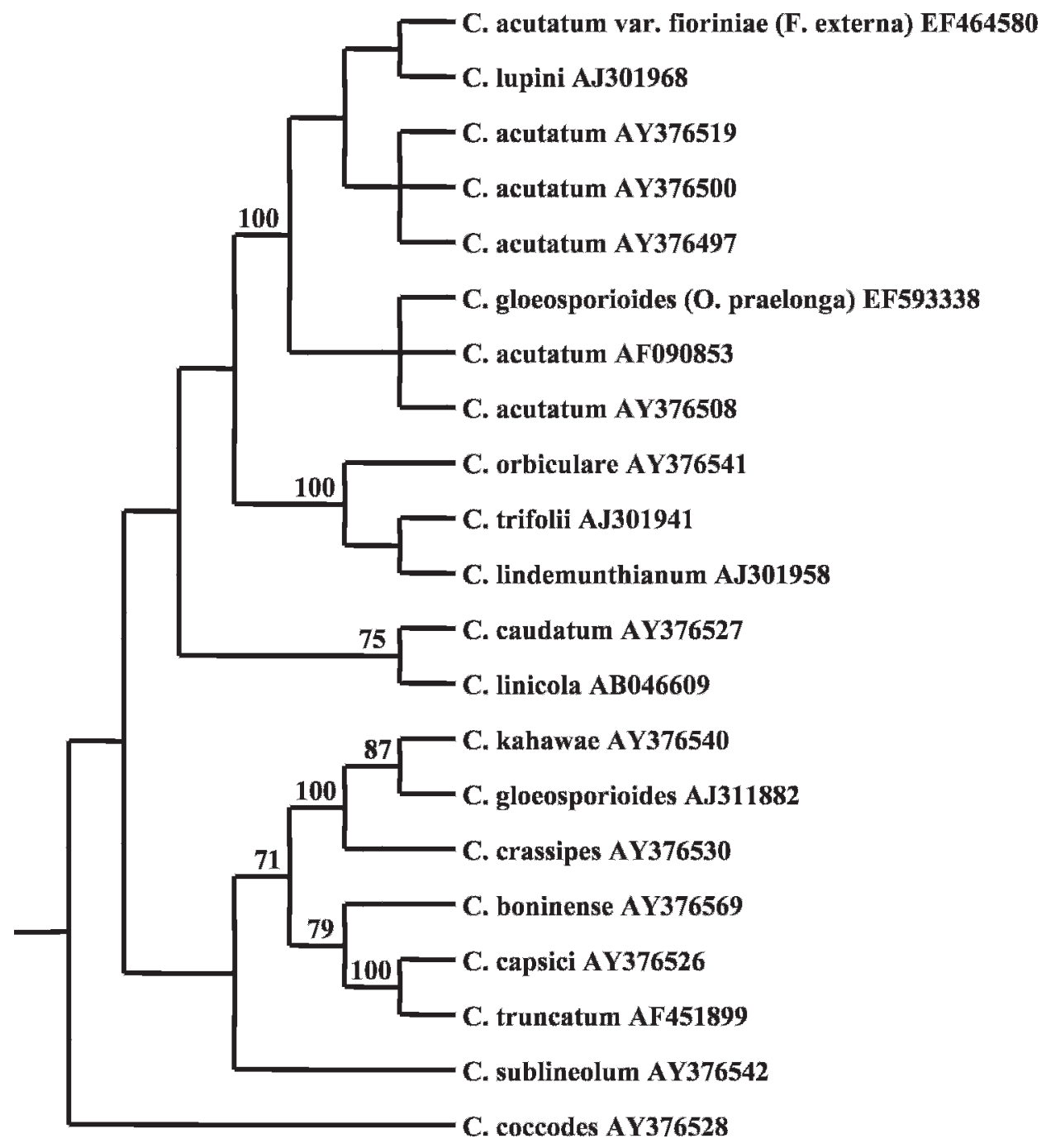

FIG. 3. Phylogenetic tree (Inferred MP tree) among Colletotrichum spp. and Colletotrichum sp. strains isolated from Fiorinia externa for the ITS region. Consensus of three equally parsimonious trees. Numbers above nodes are bootstrap values based on 1000 iterations with 30 random additions each. Only branches with values above 70 are considered well supported.

other known Colletotrichum sp. to cause an epizootic in insects, C. gloeosporioides f. sp. ortheziidae, obtained from two distant geographic localities from its epizootic areas in Rio de Janeiro and São Paulo, Brazil.

Our morphological and molecular data indicated that the fungus isolated from F. externa in the epizootic belonged to the genus Colletotrichum and that it was identical to the species C. acutatum. Colletotrichum affects a wide variety of plants (Lenné 1992, Lardner et al 1999, Moriwaki et al 2002) with C. acutatum and $C$. gloeosporioides known to be the most cosmopolitan species. Reports of plant pathogens infecting insects are uncommon. Within the genus Colletotrichum there is only one other published case, that of C. gloeosporioides f. sp. ortheziidae infecting the scale Orthezia praelonga in Brazil (Cesnik and Ferraz 2000). Our data indicate that C. acutatum var. fioriniae is associated with the epizootic in F. externa. The phylogenetic analysis obtained from four of the six genes, ITS (FIG. 3), GS (FIG. 4), GPDH (FIG. 5) and $\beta$-tubulin2 suggests that the divergence in host utilization, from plant to insect, of both C. acutatum var. fioriniae and $C$. gloeosporiodies f. sp. ortheziidae are independent events. However, when using the HMG at the MAT1-2 gene, both (FIG. 6) taxa form a monophyletic group, perhaps due to sampling error. Both Colletotrichum strains retrieved from $F$. externa and $O$. praelonga appear to be derived from C. acutatum.

With the exception of conidia and ascospore size, there is congruence between the two reliable morphological measurements and results obtained with molecular data. Thus we name this fungus isolated from $F$. externa in the northeastern epizootic region of USA C. acutatum var. fioriniae var. nov. 


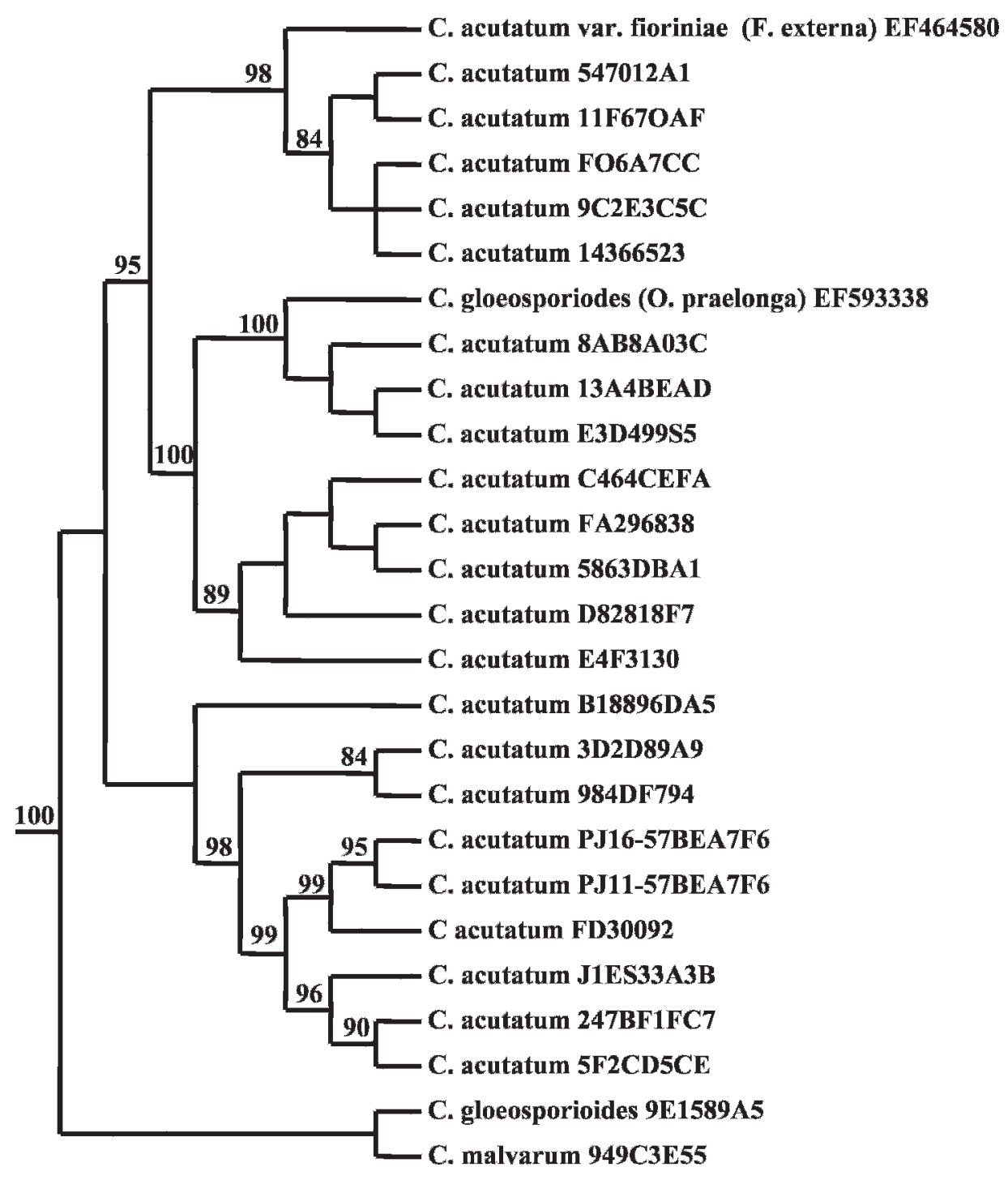

FIG. 4. Phylogenetic tree (Inferred MP tree) among Colletotrichum spp. and Colletotrichum sp. strains isolated from Fiorinia externa for the GS gene. Consensus of nine equally parsimonious trees. Numbers above nodes are bootstrap values based on 1000 iterations with 30 random additions each. Only branches with values above 70 are considered well supported.

We observed an array of phenotypes and sectors in cultures for Colletotrichum sp. recovered from $F$. externa. The highest level of variability in pigmentation occurred at $20 \mathrm{C}$ and the lowest at $10 \mathrm{C}$. Fungal phenotypic plasticity and sectoring is a common phenomenon in vitro found to be associated with several species of fungi including Colletotrichum and attributed to mutations, retrotransposons and recombination (Zhu and Oudemans 2000, Perkins et al 2001, Kaboré et al 2001, Takano et al 2001, Li et al 2005). However the C. a. fioriniae phenotype was unusual in that we observed up to five pigments in both the mycelium and medium in pure cultures. This variation demonstrates a high rate of morpho- logical/physiological heterogeneity in this variety of C. acutatum. In contrast the two C. gloeosporioides f. sp. ortheziidae Brazilian strains tested did not display this plasticity in culture, presenting a consistent orange $\left(\mathrm{ARSEF}_{4360}\right)$ and gray mycelia $\left(\mathrm{EMA}_{26}\right)$ at both $15 \mathrm{C}$ and $25 \mathrm{C}$.

Conidia of the 26 isolates of the entomopathogenic Colletotrichum sp. were smaller $(5.61-8.57 \mu \mathrm{m})$ than the reported length for the C. acutatum species complex. The two entomopathogenic strains of $C$. gloeosporioides $\mathrm{f}$. sp. ortheziidae, also produced smaller conidia, than that reported for the C. gloeosporioides species complex. Appresoria length and width of both Colletotrichum sp. and C. gloeosporioides f. sp. orthezii- 


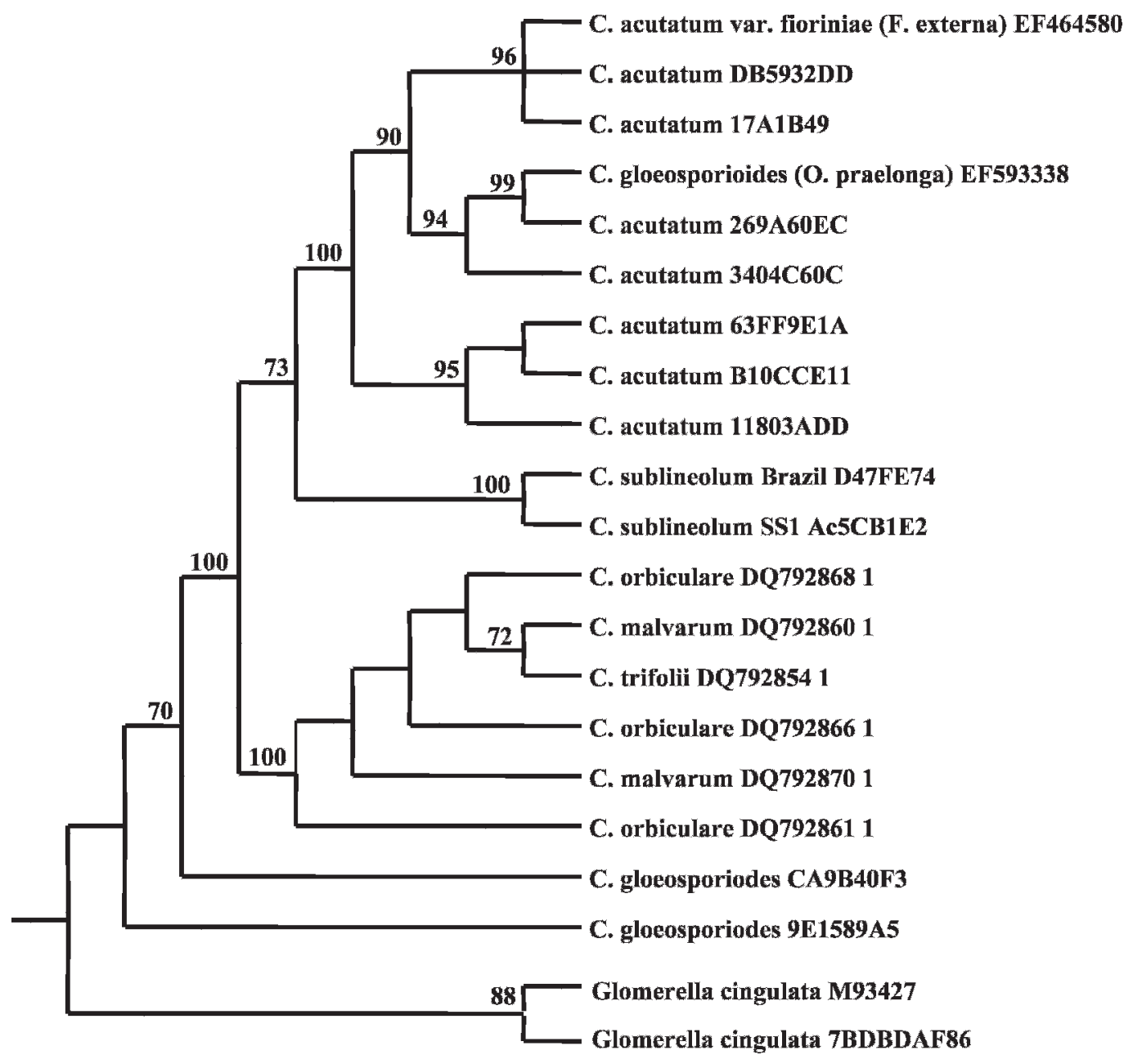

FIG. 5. Phylogenetic tree (Inferred MP tree) among Colletotrichum spp. and Colletotrichum sp. strains isolated from Fiorinia externa, for the GPDH gene. Consensus of 350 equally parsimonious trees. Numbers above nodes are bootstrap values based on 1000 iterations with 30 random additions each. Only branches with values above 70 are considered well supported.

dae were consistently within the lower range of that reported for C. acutatum and C. gloeosporiodes. In both species appresoria were mainly ovoid.

Segregation of species based on morphological characters in the genus Colletotrichum has been based primarily on measurements of appresoria. Although we found that conidial size for both entomopathogenic strains from USA and Brazil are outside the reported range for other Colletotrichum strains, we do not believe that this result alone is a reliable means of differentiating species because the standard method for measuring spores is inconsistent. The method involves placing propagules, suspended in water on a slide, where they can be oriented in different directions or can move due to brownian motion, hence biasing readings. In contrast these problems are avoided when measuring appresoria using the Scotch ${ }^{\mathrm{TM}}$ tape print technique (Gouli et al 2005).
Therefore it is not surprising that the appresoria measurements made for Colletotrichum sp. and $C$. gloeosporioides $\mathrm{f}$. sp. ortheziidae fit within the range of Colletotrichum albeit in the lower range of the spectrum.

We detected sexual reproduction in planta using snap bean as a substratum in crosses between Colletotrichum sp. strains from $F$. externa and from a tulip tree from the epizootic area. Successful sexual reproduction also was detected in vitro after $1 \mathrm{wk}$ culturing of stems excised from beans and cultured on MSM. However reproduction was stalled when birch toothpicks were used as a substratum and no reproduction was observed with strawberry stems. Self fertilizing was detected in a self-cross with the entomopathogenic Colletotrichum sp. (strain $\mathrm{EHS}_{58}$ $\times$ EHS $\left._{58}\right)$. Our data cannot differentiate as to whether the sexual cross obtained between Colleto- 


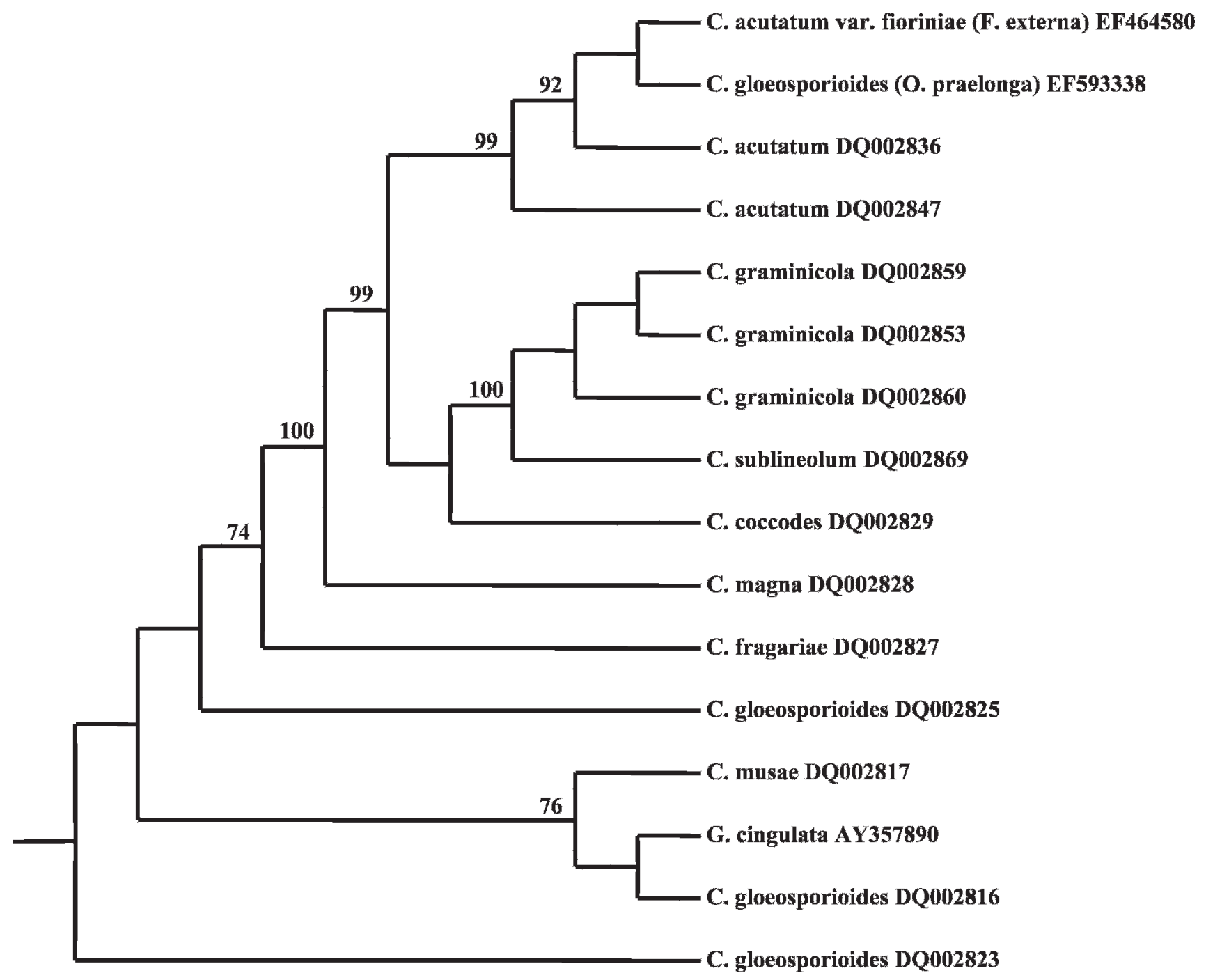

FIG. 6. Phylogenetic tree (inferred MP tree)for Colletotrichum spp. and Colletotrichum sp. strains isolated from Fiorinia externa,for High Mobility Box at the MAT 1-2 locus. Consensus of two equally parsimonious trees. Numbers above nodes are bootstrap values based on 1000 iterations with 30 random additions each. Only branches with values above 70 are considered well supported.

trichum sp. from F. externa and Colletotrichum sp. from a tulip tree was homothallic or heterothallic because we obtained the perfect stage (Glomerella) with different and same strain crosses. However these crosses do indicate that sexual reproduction can occur in this strain, possibly resulting in the adaptation to new hosts (Guerber and Correll 2001) and generation of new biotypes.

The crosses observed in beans were fertile. Perithecia, produced by the perfect stage of Colletotrichum (= Glomerella), generated asci containing eight ascospores. The mean range for the perithecia (length $\times$ width) retrieved after excised stems were placed in MSM were not within the reported range of Glomerella acutata $(115.39 \times 108.83 \mu \mathrm{m})$, whereas perithecia retrieved directly from stems in planta were within the reported range of $G$. acutata $(198.68 \times 183.43 \mu \mathrm{m})$. Size differences also were observed with perithecia retrieved from excised stems after 1 wk of culturing on MSM, presenting a mean area almost four times smaller than the area of the ones retrieved directly in planta (TABLE VI). Differences in the size of the ascospores produced in asci by the two types of perithecia also were found, with ascospores produced in perithecia directly retrieved from the stems being slightly smaller than the ones from perithecia in snap bean stems cultured in MSM. Incongruence between the size of perithecia and ascospores might result from differences in the environments in which the fruiting bodies were obtained. Perithecia values 
within the reported range were obtained from plants reared in a greenhouse with natural photoperiod, whereas smaller and out of range values were obtained from plant material in Petri dishes, in MSM media, in a growing chamber at a constant 8:16 h photoperiod (L:D) and sealed with parafilm. Like the previously reported conidial spore measurements, and for similar reasons discussed above, the ascospores of Glomerella sp. were not within the reported range for G. acutata.

Our molecular data indicate that a single population lineage of Colletotrichum from $F$. externa, henceforth referred as Colletotrichum acutatum var. fioriniae, is present in the sampled epizootic area. A RAPD analysis (FIG. 2) shows molecular homogeneity in C. acutatum var. fioriniae strains sampled within the epizootic and a C. acutatum obtained from blueberry. However differences were found between these apparently homologous strains and that obtained from C. gloeosporioides f. sp. ortheziidae.

A similar pattern was seen when six nuclear genes (i.e. the D1/D2 region of the $28 \mathrm{~S}$ ribosomal DNA, ITS region, $\beta$-tubulin 2 gene, GPDH gene, GS gene and the high mobility group of the mating-type gene, MAT1-2) were analyzed for these taxa. No differences were found between the C. acutatum var. fioriniae strains collected within the area of the epizootic and C. acutatum from a blueberry. As with the RAPD analysis, differences where found in the genes analyzed among C. acutatum var. fioriniae and C. acutatum strains and C. gloeosporioides f. sp. ortheziidae.

A BLAST analysis of data in GenBank with sequences of the nuclear genes listed above, obtained from both Colletotrichum acutatum var. fioriniae and C. gloeosporioides f. sp. ortheziidae, retrieved records of C. acutatum, some of which were identical. In addition when using the ITS sequence we also retrieved another identical taxa, C. lupini (AJ301968).

Data collected indicates that C. gloesporioides f. sp. ortheziidae appears to have attained specificity for Orthezia praelonga (Teixeira et al 2001, Jonsson and Genthner 1997, Castro et al 1998). This form is being used effectively as a biological control agent in Brazil (Cesnik and Ferraz 2000) and is under commercialization (R. Cesnik pers comm). It is possible that these two strains of Colletotrichum are at different stages of a host adaptation process. Data collected suggests that while Colletotrichum acutatum var. fioriniae still retains some capacity to invade plants endophytically (Marcelino et al 2008b), C. gloeosporioides f. sp. ortheziidae appears to have lost this capacity.

It has been suggested that $C$. acutatum might have a broader host range than what has been reported (Peres et al 2005). The cosmopolitan preference of this species for plants may pre-adapt it to infect radically different hosts. The means by which such wide range of preference in hosts can be achieved by this pathogen are uncertain (Wei et al 2004). The ability to expand host range can result from genetic variation subsequent to sexual crossing. While we do not know whether Colletotrichum acutatum var. fioriniae can produce a heterothallic cross, we have induced an homothallic cross and generated the sexual stage, Glomerella, in our crosses. It is possible that Colletotrichum acutatum var. fioriniae with its new propensity to infect insects instead of plants might have resulted from same sex mating. This type of reproductive strategy would produce meiotic clones, perhaps explaining the molecular homogeneity of the Colletotrichum acutatum var. fioriniae strains sampled within the area of the epizootic. A similar case of recombination via same-sex mating and subsequent expansion to new geographical niches has recently been reported for Cryptococcus gattii (Fraser et al 2005).

In most Colletotrichum spp. affecting plants the prevalent mode of reproduction is clonal, however heterothallic intercompatibility has been reported (Roca et al 2004, Vaillancourt et al 2000, Crouch et al 2005).

The northeastern USA forest area where the epizootic has occurred provides optimal conditions for the growth of Colletotrichum acutatum var. fioriniae, which might have aided sexual crossing in this strain. Hemlock stands typically grow in riparian areas that help create a microclimate where relative humidity as a rule can reach $80 \%$ in the summer and attain $80 \mathrm{~d} / \mathrm{y}$ of mist (Baldwin 1973, McGuire and Forman 1983). This environment also might aid the endophytic infection of plants in the area where infected insects occur. The propensity of C. acutatum to endophytically colonize plants adjacent to infected hosts also has been shown by Freeman et al (2001). Endophytic infections might function as a reservoir and play a role in maintaining the infection in the environment.

The capacity of Colletotrichum acutatum var. fioriniae to infect members of two kingdoms widens the host range for this species. The classification of members of this genus is in part determined by the identity of their hosts. The identification of a strain which affects a wide variety of plants as well as an insect illustrates the difficulties inherent in using host identity for species segregation. This work indicates that many characters, including morphological and molecular, should be used to classify members of this genus. 


\section{ACKNOWLEDGMENTS}

We thank Mr Fred Little and Mr Jeff Grosse for transcribing nonpublished genetic sequences in Liu 2002. We also thank Drs Felipe Soto for assistance with molecular analysis and Carol Shearer for comments on the manuscript. This work was financed in part through a grant awarded by the Northeastern Area State and Private Forestry, USDA Forest Service (No. 04-CA-11244225286) and is in partial fulfillment of requirements for the doctoral degree of JM at the University of Vermont.

\section{LITERATURE CITED}

Afanador-Kafuri L, Minz D, Maymon M, Freeman S. 2003. Characterization of Colletotrichum isolates from tamarillo, passiflora, and mango in Colombia and identification of a unique species from the genus. Phytopathology 93:579-587.

Baldwin JL. 1973. Climates of the United States. Washington D.C.: U.S. Department of Commerce. 113 p.

Batista AC, Bezerra JL. 1966. Sobre o parasitismo de Colletotrichum gloeosporioides e outros fungos em Orthezia praelonga Douglas. Brotéria 35:68-74 (In Portuguese).

Castro VL, Cesnik R, Oliveira RCAL. 1998. Testes toxicológicos em ratos expostos ao Colletotrichum gloeosporioides. 6 Simpósio de Controle Biológico. Rio de Janeiro, Brazil. 156 p (In Portuguese).

Cesnik R, Ferraz JNG, Oliveira RCAL, Arellano F, Maia AH. 1996. Controle de Orthezia praelonga com o fungo Colletotrichum gloeosporioides isolado orthezia, na regiao de Limeira, SP. 5 Simpósio de Controle Biológico. Foz de Iguaçu, Brazil. 363 p (In Portuguese).

2000. Orthezia praelonga, 1891 (Hemiptera, Ortheziidae) biologia, controle químico e biológico. Jaguariúna: embrapa meio ambiente. Boletim Pesquisa 9:27 (In Portuguese).

Cisar CR, Thornton AB, TeBeest DO. 1996. Isolates of Colletotrichum gloeosporioides (Telemorph: Glomerella cingulata) with different host specificities mate on Northern Jointvetch. Biol Control 7:75-83.

Chenna R, Sugawara H, Koike T, Lopez R, Gibson TJ, Higgins DG, Thompson JD. 2003. Multiple sequence alignment with the Clustal series of programs. Nucleic Acid Res 31(13):3497-500.

Clamp M, Cuff J, Searle SM, Barton GJ. 2004. The Jalview java alignment editor. Bioinformatics 20:426-427.

Corda AKJ. 1831. Die Pilze Deutschlands. In: Sturm J., ed., Deutschlands Flora 3. Abtheilung 3(12):33-64.

Crouch JA, Clarke BB, Hillman BI. 2005. Diversity in natural populations of Colletotrichum from the tall grass prairie. 23rd Fungal Genetics Conference. 15-20 Mar 2005. Asilomar, California. (Abstract)

Crow TR. 1995. The social, economic, and ecological significance of hemlock in the Lake states. In: Mroz G, Martin AJ, eds. Hemlock ecology and management. Proceedings of a regional conference on ecology and management of eastern hemlock Department of Forestry, University of Wisconsin. p 11-17.
Danoff-Burg JA, Bird S. 2002. Hemlock woolly adelgid and elongate hemlock scale: partners in crime? In: Onken B, Reardon R, Lashomb J, eds. Proceedings of the hemlock wooly adelgid in the eastern United States Symposium, 5-7 Feb 2002. New Brunswick: New Jersey Agricultural Experiment Station, Rutgers University. p 254-268.

Dwyer G, Elkinton JS, Hajek AE. 1998. Spatial scale and the spread of a fungal pathogen of gypsy moth. Am Natural 152(3):485-494.

Du M, Schardl CL, Nuckles EM, Vaillancourt LJ. 2005. Using mating-type gene sequences for improved phylogenetic resolution of Colletotrichum species complexes. Mycologia 97:641-658.

Foster DR, Zebryk TM. 1993. Long-term vegetation dynamics and disturbance history of a Tsuga-dominated forest in New England. Ecology 74(4):982-998.

Fraser JA, Giles SS, Wenink EC, Geunes-Boyer SG, Wright JR, Diezmann S, Allen A, Stajich JE, Dietrich FS, Perfect JR, Heitman J. 2005. Same-sex mating and the origin of the Vancouver Island Cryptococcus gattii outbreak. Nature 437:1360-1364.

Freeman S, Shabi E, Katan T. 1995. Characterization of Colletotrichum acutatum causing anthracnose of anemone (Anemone coronaria L.). App Enviro Microbio $66(12): 5267-5272$.

_- Horowitz S, Sharon A. 2001. Pathogenic and nonpathogenic lifestyles in Colletotrichum acutatum from strawberry and other plants. Phytophathology 91:986-992.

Gouli VV, Gouli SY, Costa SD, Shternshi MV. 2005. Comparison of wash, leaf imprint and adhesive tape methods for estimation of fungal spore deposition on leaves. J Mycol Phytopathol 39:99-103 (In German).

Guerber JC, Correll JC. 2001. Morphological description of Glomerella acutata, the teleomorph of Colletotrichum acutatum. Mycologia 93:216-229.

Griffin MS, Sutheereland JR, Dennis JJ. 1987. Blight of conifer seedlings caused by Colletotrichum gloeosporioides. New Forest 1:81-88.

Gupta M, Filner P. 1991. Microsatellites amplify highly polymorphic DNA bands in SPAR of plant DNA. In: Proceedings of the International Society of Plant Moleular Biology. Tucson, Arizona, 1705 p (Abstract).

Hajek AE, Elkinton JS, Witcosky JJ. 1996. Introduction and spread of the fungal pathogen Entomophaga maimaga (Zygomycetes: Enthomophthorales) along the leading edge of gypsy moth (Lepidoptera: Lymantriidae) spread. Bio Control 25(5):1236-1247.

Howard T, Sendak P, Codrescu C. 2000. Eastern hemlock: a market perspective. In: McManus KA, Shields KS, Souto DR, eds. Proceedings of the symposium on sustainable management of hemlock ecosystems in eastern North America. Durham, New Hampshite: USDA Forest Service. p 161-166.

Howe RW, Mossman M. 1995. The significance of hemlock for breeding birds in the Western Great Lakes region. In: Mroz G, Martin AJ, eds. Hemlock ecology and management. Proceedings of a regional conference on 
ecology and management of eastern hemlock Department of Forestry, University of Wisconsin. p 125-140.

Hillis DM, Dixon MT. 1991. Ribosomal DNA: molecular evolution and phylogenetic inference. Q Rev Biol 66: 411-453.

Hopkins JC, Lock W, Funk A. 1985. Colletotrichum acutatum, a new pathogen on western hemlock seedlings in British Columbia. Can Plant Dis Surv 65:11-13.

Kaboré BK, Couture L, Dostaler D, Bernier L. 2001. Variabilité phénétique du Colletotrichum graminicola du sorgho. Can J Plant Pathol 23:138-145 (In French).

Keller S, Schweizer C, Keller E, Brenner H. 1997. Control of white grub (Melolontha melolontha L.) by treating adults with the fungus Beauvaria brongniartii. Biocontrol Sci Tech 7:105-116.

Inglis GD, Goettel MS, Butt TM, Strasser H. 2001. Use of Hypomycetous fungi for managing insect pests. In: Butt TM, Jackson C, Magan N, eds. Fungi as biocontrol agents CAB International. p 23-71.

Johnson WT, Lyon HH. 1998. Insects that feed on trees and shrubs. 2nd ed Cornell Univ. Press. 556 p.

Jonsson CM, Genthner FJ. 1997. Avaliação do potencial de patogenicidade e toxicidade do fungo entomopatógeno Colletotrichum gloeosporioides isolados de Orthezia em duas espécies de crustáceos. Bol Pesqui EmbrapaCNPMA 1:1-27 (In Portuguese).

Lambdin P, Lynch C, Grant J, Reardon R, Onken B, Rhea R. 2005. Elongate hemlock scale and its natural enemies in the southern Appalachians. In: Onken B, Reardon $\mathrm{R}$, eds. 3rd symposium on hemlock woolly adelgid in the eastern United States USDA Forest Service. p 145154.

Lardner R, Johnston PR, Plummer KM, Pearson MN. 1999. Morphological and molecular analysis of Colletotrichum acutatum sensu lato. Mycol Res 103:275-285.

Lenné JM. 1992. Colletotrichum diseases of legumes. In: Bailey JA, Jeger MJ, eds. Colletotrichum: biology, pathology and control. Wallingford, UK: CAB International. p 135-166.

Li D, Bobrowicz P, Wilkinson HH, Ebbole DJ. 2005. A Mitogen-Activated protein kinase pathway essential for mating and contributing to vegetative growth in Neurospora crassa. Genetics 170:1091-1104.

Liu B. 2002. Molecular characterization and inter and intra species phylogenetic relationships in the fungal plant pathogen Colletotrichum [Doctoral dissertation]. Fayetteville: University of Arkansas. 286 p.

Lubbe CM, Denman S, Cannon PF, Groenewald JZ, Lamprecht SC, Crous PW. 2004. Characterization of species associated with diseases of Proteaceae. Mycologia 96(6):1268-1279.

Maddison WP, Maddison JR. 1992. MacClade: analysis of phylogeny and character evolution. Sunderland, Massachusetts: Sinauer Associates.

Marcelino JAP, Gouli S, Gouli V, Parker BL, Skinner M, Giordano R. 2008a. Entomopathogenic activity of a Colletotrichum acutatum variety recovered from Fiorinia externa. J Insect Sci. (In press).

— - - Parker BL, Skinner M, Schwarzberg L, Giordano R. 2008b. Host plant associations of an entomopathogenic variety of the fungus Colletotrichum acutatum recovered from the Elongate Hemlock Scale, Fiorinia externa. J Insect Sci. (In press).

McClure MS. 1978a. Self regulation in scale insect populations on hemlock. New York Entomological Society 86(4):309.

. 1978b. Seasonal development of Fiorinia externa, Tsugaspidiotus tsugae (Homoptera: Diaspididae), and their parasite, Aspidiotiphagus citrinus (Hymenoptera: Aphelinidae): importance of parasite-host synchronism to the population dynamics of two scale pests of hemlocks. Environ Entomol 7:863-870.

2002. The elongate hemlock scale, Fiorinia externa Ferris (Hemiptera: Diaspididae): A new look at an old nemesis. In: Onken B, Reardon R, Lashomb J, eds. Proceedings of hemlock woolly adelgid in the eastern United States Symposium. New Brunswick: New Jersey Agricultural Experiment Station, Rutgers University. p 248-253.

McGuire DA, Forman RTT. 1983. Herb cover effects on tree seedling patterns in a mature hemlock-hardwood forest. Ecology 64:1367-1380.

Meekes ETM, van Voorst S, Joosten NN, Fransen JJ. 2000. Persistence of the fungal whitefly pathogen, Aschersonia aleyrodis, on three different plant species. Mycol Res 104(10):1234-1240.

Metamorph Imaging System. 2003. Meta imaging series MetaMorph basic commands. Version 6.1 for Microsoft Windows 2000/XP. User's Guide. Downingtown, Pennsylvania: Universal Imaging Corp.

Mills PR, Sreenivasaprasad S, Brown AE. 1992. Detection and differentiation of Colletotrichum gloeosporioides isolates using PCR. FEMS Microbiol Lett 98:137-144.

Mladenoff DJ. 1995. The role of eastern hemlock across scales in the northern lake states. In: Mroz G, Martin AJ, eds. Hemlock ecology and management. Proceedings of a regional conference on ecology and management of eastern hemlock Department of Forestry, University of Wisconsin. p 29-42.

Moriwaki J, Tsukiboshi T, Sato T. 2002. Grouping of Colletotrichum species in Japan based on rDNA sequences. J Gen Plant Pathol 68:307-320.

Negasi AN, Parker BL, Brownbridge M. 1998. Screening and bioassay of entomopathogenic fungi for the control of silverleaf whitefly. Insect Sci Applic 18:37-44.

Nirenberg HI, Feiler U, Hagedorn G. 2002. Description of Colletotrichum lupini comb. nov. in modern terms. Mycologia 94:307-320.

O'Donnell K. 1992. Ribosomal DNA internal transcribed spacers are highly divergent in the phytopathogenic ascomycete Fusarium sambucinum (Gibberella pulicaris). Curr Genet 22:213-220.

- 1993. Fusarium and its near relatives. In: Reynolds $\mathrm{R}$, Taylor JW, eds. The fungal holomorph: mitotic, meiotic and pleomorphic speciation in fungal systematics. Wallingford, UK: CAB International. p 225-233.

Otvos IS. 2004. Integrated Pest Management in Forestry: Potential and Challenges. In: Koul O, Dhaliwal GS, Cuperus GW, eds. Integrated Pest Management Poten- 
tial, Constraints and Challenges. Wallingford, UK: CAB International.

Pannacione DG, Hanau RM. 1990. Characterization of two divergent $\beta$-tubulin genes from Colletotrichum graminicola. Gene 86:163-170.

Parker BL, Skinner M, Gouli V, Gouli S, Marcelino JAP, Carlson J, Schwartzberg L. 2005. Management of elongate hemlock scale with entomopathogenic fungi. In: Onken B, Reardon R, eds. 3rd symposium on hemlock woolly adelgid in the eastern Unites States. Asheville, North Carolina. 1-3 Feb 2005. p 161-168.

Peres NA, Timmer LW, Adaskaveg JE, Correll JC. 2005. Lifestyles of Colletotrichum acutatum. Plant Dis 89:784796.

Perkins DD, Radford A, Sachs MS. 2001. The Neurospora Compendium. San Diego: Academic Press. 325 p.

Roca MG, Davide LC, Davide LMC, Mendes-Costa MC, Schwan RF, Wheals AE. 2004. Conidial anastomosis fusions between Colletotrichum spp. Mycol Res 108(11):1320-1326.

Royle DD, Lathrop RG. 2002. Using Landsat imagery to quantify temporal and spatial patterns in hemlock decline. In: Onken B, Reardon R, Lashomb J, eds. Proceedings of the hemlock woolly adelgid in the eastern United States symposium. New Brunswick: New Jersey Agricultural Experiment Station, Rutgers University. p 67-72.

SAS Institute. 1990. SAS/STAT user's guide. 4th ed. Cary, North Carolina: C. SAS Institute.

Sharon A, Yamaguchi K, Christiansen S, Horwitz BA, Yoder OC, Turgeon BG. 1996. An asexual fungus has the potential for sexual development. Mol Gen Genet 251: 60-68.

Simmonds JH. 1965. A study of the species of Colletotrichum causing ripe fruit rots in Queensland. Queensl J Ag Anim Sci 22:437-459.

Smith JE, Korsten LK, Aveling TASA. 1999. Infection process of Colletotrichum demantium on cowpea stems. Mycol Res 103(2):230-234.

Snyder CD, Young JA, Lemarie DP, Smith DR. 2002. Influence of eastern hemlock (Tsuga canadensis) forests on aquatic invertebrate assemblages in headwater streams. Can J Fish Aquat Sci 59(2):262-275.

Stephenson SA, Green JR, Manners JM, Maclean DJ. 1997. Cloning and characterization of glutamine synthetase from Colletotrichum gloeosporioides and demonstration of elevated expression during pathogenesis on Stylosanthes guianensis. Curr Genet 31:447-54.

Sutton BC. 1992. The genus Glomerella and its anamorph Colletotrichum. In: Bailey JA, Jeger MJ, eds. Colletotrichum-biology, pathology and control. Wallingford, UK: CAB International. p 1-26.

Swofford DL. 2002. PAUP*: phylogenetic analysis using parsimony (*and other methods). Version 10. Sunderland, Massachusetts: Sinauer Associates.

Takano Y, Kikuchi T, Kubo Y, Hamer JE, Mise K, Furusawa I. 2000. The Colletotrichum lagenarium MAP kinase gene CMK1 regulates diverse aspects of fungal pathogenesis. Mol Plant Microbe Interact 13:374-383.

Talhinhas P, Sreenivasaprasad S, Neves-Martins J, Oliveira
H. 2002. Genetic and molecular characterization of Colletotrichum acutatum causing anthracnose of lupins. Phytopathology 92:986-996.

— $-\longrightarrow$, ——. 2005. Molecular and phenotypic analysis reveals the association of diverse Colletotrichum acutatum groups and a low level of $C$. gloeosporioides with olive anthracnose. Appl Environ Microbiol 71(6):2987-2998.

TeBeest DO. 1988. Additions to host range of Colletotrichum gloeosporioides f. sp. aeschynomene. Plant Dis 72:16-21.

Templeton MD, Rikkerink EH, Solon SL, Crowhurst RN. 1992. Cloning and molecular characterization of the glyceraldehyde-3-phosphate dehydrogenase-encoding gene and cDNA from the plant pathogenic fungus Glomerella cingulata. Gene 122(1):225-230.

Teixeira MA, Bettiol W, Cesnik R. 2001. Pathogenicity of Coletotrichum gloeosporioides, Orthezia praelonga pathogenic agent, to citrus leaves, flowers and fruits. Summa Phytopathol 27:352-357 (In Portuguese).

Thon MR, Royse DJ. 1999. Partial $\beta$-tubulin gene sequences for evolutionary studies in the Basidiomycota. Mycologia 91(3):468-474.

Turgeon BG. 1998. Application of mating-type gene technology to problems in fungal biology. Ann Rev Phytopathol 36:115-137.

USDA Forest Service. 2004. Forest insects and diseases conditions in the United States 2003. USDA Forest Serv. Publ. 142 p.

Vaillancourt LJ, Du M, Wang J, Rollins J, Hanau RM. 2000. Genetic analysis of cross fertility between two self-sterile strains of Glomerella graminicola. Mycologia 92:430435.

Viegas EC, Sampaio HN, Carvalho POL, Perruso JC, Cassino PCR. 1995. Contole alternative de Orthezia praelonga Douglas, 1891 (Hemiptera, Ortheziidae) em laboratório. In: 15 Congresso de Entomologia. 12-17 Mar 1995, Caxambú, Brazil, 333 p (In Portuguese).

Waller JM. 1992. Colletotrichum diseases of perennial and other cash crops, Bailey JA, Jeger MJ, eds. Colletotrichum-biology, pathology and control. Wallingford, UK: CAB International. p 167-201.

Wei YD, Shen W, Dauk M, Wang F, Selvaraj G, Zou J. 2004. Targeted-gene disruption of glycerol-3-phosphate dehydrogenase in Colletotrichum gloeosporioides reveals evidence that glycerol is a transferred nutrient from host plant to fungal pathogen. J Biol Chem 279:429 435.

Weising K, Weigand F, Driesel AJ, Kahl G, Zischer H. 1989. Polymorphic simple GATA/GACA repeats in plant genomes. Nucleic Acid Res 17:10128.

White TJ, Bruns T, Lee S, Taylor JW. 1990. Amplification and direct sequencing of fungal ribosomal RNA genes for phylogenetics. In: Innis MA, Gelfand DH, Sninsky JJ, White TJ, eds. PCR protocols: a guide to methods and applications. New York: Academic Press. p 315322.

Wraight SP, Jackson MA, Kock SL. 2001. Production, stabilization and formulation of biocontrol agents. In: Butt TM, Jackson C, Magan N, eds. Fungi as biocontrol agents CAB International. p 253-288. 
Wydeven AP, Hay RW. 1995. Mammals, amphibians and reptiles of hemlock forests in the Lake Superior region. In: Mroz G, Martin AJm, eds. Hemlock ecology and management. Proceedings of a regional conference on ecology and management of eastern hemlock Department of Forestry, University of Wisconsin. p 115-123.

Xiao CL, MacKenzie SJ, Legard DE. 2004. Genetic and pathogenic analysis of Colletotrichum gloeosporioides isolates from strawberry and non-cultivated hosts. Phytopathology 94:446-453.

Zhu P, Oudemans PV. 2000. A long terminal repeat retrotransposon Cgret from the phytopathogenic fungus Colletotrichum gloeosporioides on cranberry. Curr Genet 38:241-7. 